\title{
GEOMORPHOLOGICAL CHARACTERISTICS OF THE MASSIF PRENJ
}

\section{GEOMORFOLOŠKE ZNAČILNOSTI PRENJSKEGA MASIVA}

\author{
Alen LEPIRICA ${ }^{1}$
}

\begin{abstract}
UDC 911.2:551.435.1(497.6)

Alen Lepirica: Geomorphological characteristics of the massif Prenj
\end{abstract}

The researched area of the mountain massif Prenj with surface of $463 \mathrm{~km}^{2}$ is located in the zone of high karst of Outer Dinarides of Bosnia and Herzegovina. It is circular mountain morphostructure with assymetrical transversal profile. Developed in Mesozoic subhorizontal layers of limestone and dolomite over 3500 thick, fissured by numerous reverse and normal faults. Prenj is folded-thrusted mountain massif (2103 m a.s.l.) uplifted during neotectonic phase of Dinarides development, structurally represented by three blocks. A high degree of correlation between lithology, fault structures and relief has been determinated. The main fault structures caused by rotation of Prenj blocks which were reflected on different orientations of stretching of the mountain ridges and composite valleys of Neretva, Konjička Bijela, Mostarska Bijela, Glogošnica and Idbar. Thrusts express tectonic, lithological, and morphological border of the considered mountain with inter mountain Neogene depressions in the North and South. Netectonic movements and dominanting carbonate composition of the terrain have influenced on reticular relief structure of the massif. Linear landforms of ridges formed in karst are neotectonically, rectilinearly and half-arc elongated up to $12 \mathrm{~km}$. In regards to morphogenesis during the Quaternary, the massif is characterized by development: derasional, glacial, periglacial, karstic, fluviokarstic, fluviodenudational and fluvial erosional and accumulational processes and landforms. Finally, geomorphological regionalization of Prenj was made on the basis of the criteria of similarity of morpho-evolutionary, structural-lithological and orographical characteristics.

Key words: Folded-thrusted mountain massif, processes and landforms, geomorphological regionalisation, high Dinaric karst, Prenj, Bosnia and Herzegovina.
Izvleček

UDK 911.2:551.435.1(497.6)

Alen Lepirica: Geomorfološke značilnosti Prenjskega masiva

Obravnavano območje Prenjskega gorskega masiva, ki obsega površino $463 \mathrm{~km}^{2}$, se nahaja na predelu Visokega krasa Zunanjih Dinaridov v Bosni in Hercegovini. Masiv označuje krožna gorska morfostruktura $\mathrm{z}$ asimetričnim prečnim profilom. Območje gradijo subhorizontalne plasti apnencev in dolomitov, ki so debele preko 3500 metrov in prepredene $\mathrm{z}$ vrsto reverznih in normalnih prelomov. Prenj je gorski masiv narivno nagubane zgradbe (2103 m n.v.), dvignjen med neotektonsko fazo razvoja Dinaridov. Strukturno je razdeljen na tri bloke. Določena je bila visoka korelacija med litologijo, prelomnimi strukturami in reliefom. Glavne prelomne strukture, ki jih je povzročila rotacija prenjskih blokov odražajo različno orientacijo raztezanja gorskih grebenov in sestavljenih dolin Neretve, Konjičke Bijele, Mostarske Bijele, Glogošnice in Idbar. Narivi določajo tektonske, litološke in morfološke meje obravnavanega gorovja in vmesnih neogenskih depresij na severu in jugu. Neotektonski premiki in prevladujoča karbonatna sestava terena so vplivali na mrežasto reliefno strukturo masiva. Podolžni grebeni v krasu so neotektonsko, ravno in polločno raztegnjeni do $12 \mathrm{~km}$. Glede morfogeneze v kvartarju masiv označujejo naslednji procesi in oblike: pobočni, ledeniški, periglacialni, kraški, rečno-kraški, rečno-denudacijski in rečno-erozijski ter akumulacijski. Na koncu je narejena geomorfološka regionalizacija Prenja na podlagi kriterijev podobnosti razvoja oblik, strukturno-litoloških in orografskih značilnosti.

Ključne besede: gubasto-narivni gorski masiv, procesi in oblikovanost površja, geomorfološka regionalizacija, Visoki Dinarski kras, Prenj, Bosna in Hercegovina.

\footnotetext{
${ }^{1}$ Odsjek za geografiju, Prirodno-matematički fakultet, Univerzitet u Tuzli, Bosna i Hercegovina, e-mail: lepiricaalen@yahoo.com Received/Prejeto: 20.06 .2008
} 


\section{INTRODUCTION}

Massif Prenj is a part of the high karst zone of the Outer Dinarides of Bosnia and Herzegovina. The researched mountain morphostructure is located at the mountain part of the river basin Neretva (Fig. 1).

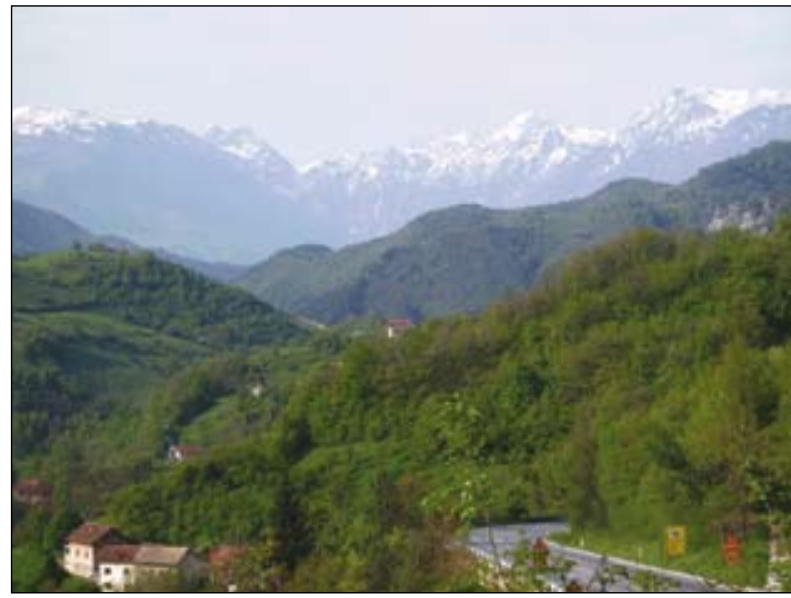

Fig. 1: Ridges and peaks of northeast Prenj in May, view from the valley of Trešanica (photo: A. Lepirica).

The first articles in the filed of geosciences that treat this and neighboring areas were published during the period of Austro-Hungarian Monarchy. A. Bittner (1888) made the first geological map in the scale of 1: 576000 in which the considered are was included. In it the sediments of the Central Prenj are represented with Jurassic and northern parts with Triassic period. Geological researches of the specific parts of the massif were undertaken by: F. Katzer (1903), T. Jakšić \& M. Milojković (1928), R. Jovanović (1953), R. Jovanović \& J. Pamić (1959-60), J. Pamić \& S. Maksimčev (1961), Đ. Čelebić (1967) and others. Tectonics of the mountain is developed by M. Mojičević \& M. Laušević (1967) and M. Miladinović, M. Mojičević, M. Laušević (1970). The above mentioned has resulted in creation of the basic geological map scale 1 : 100 000, sheet Mostar, and in publishing of its Explanation for geological map (1973).

The massif has been geomorphologically considered in the studies of: J. Cvijić (1899, 1924-26), A. Penck (1900), A. Grund (1910), J. Roglić (1959), B. Milojević (1961). These studies present karst landforms and give various hypotheses about Pleistocene glaciation. In the study of S. Bakaršić (1967) there is a detailed description of the landforms of glacial and periglacial accumulation in basin of Bijelo Polje originated from south and central slopes of Prenj.

This article presents the results of morphological and morphostructural analysis. On the basis of the field research geomorphic processes and landforms are identified, determined their development and features and spatial distribution of types of relief, and created geomorphological map of Prenj. Finally, it achieves geomorphological regionalization of the area.

\section{POSITION AND GEOLOGICAL SETTINGS}

The mountain Prenj (2103 m a.s.l.) is located in the northern Herzegovina, around $20 \mathrm{~km}$ north from the city Mostar (Fig. 2). With its specific morphology, disposition and length of its high, sharp ridges and serrated peaks presents prominent mountain massif in comparison to neighboring relief complex. More precisely, it enters into the zone of the high Herzegovinian karst (Fig. 3).

Prenj is circular morphostructure of the average diameter of $21-22 \mathrm{~km}$ with surface of $463 \mathrm{~km}^{2}$. From its center the mountain ridges are divergently extended. It is of asymmetrical transversal profile with perpendicular north and west slopes. Dissected deep incised valley of Neretva and its left tributaries: Konjička Bijela, Idbar, Glogošnica and Mostarska Bijela.

The researched area is morphostructurally and lithologically determined in the space. Intermountain depression of Neogene basin of Ostrožac - Čelebići pres- ents its northern border. With the regionally important thrust at northeast which is extended from lake Boračko jezero lower part valley of Bijela - lower valley Idbar Prenj is separated from the neighbouring areas. Eastern slopes of the massif end at the fault contact with a system uvalas shaped in karst, in the relation: Rujišta - Bahtijevica - Boračko jezero. Drežničko-Porimska thrust separates it from the south and southwest from the basin of Bijelo polje and gorge of Neretva. Ending northwest mountain slopes are perpendicularly oriented in deep incised gorge of Neretva river.

Carbonate rocks are lithologically dominant. There are over 3500 meters thick layers of Mesozoic limestone, dolomites, dolomite limestones and limestones and dolomites interchangeably (Fig. 4).

The oldest discovered layers date from low Triass. They are represented by the deposits of Scitian sedi- 


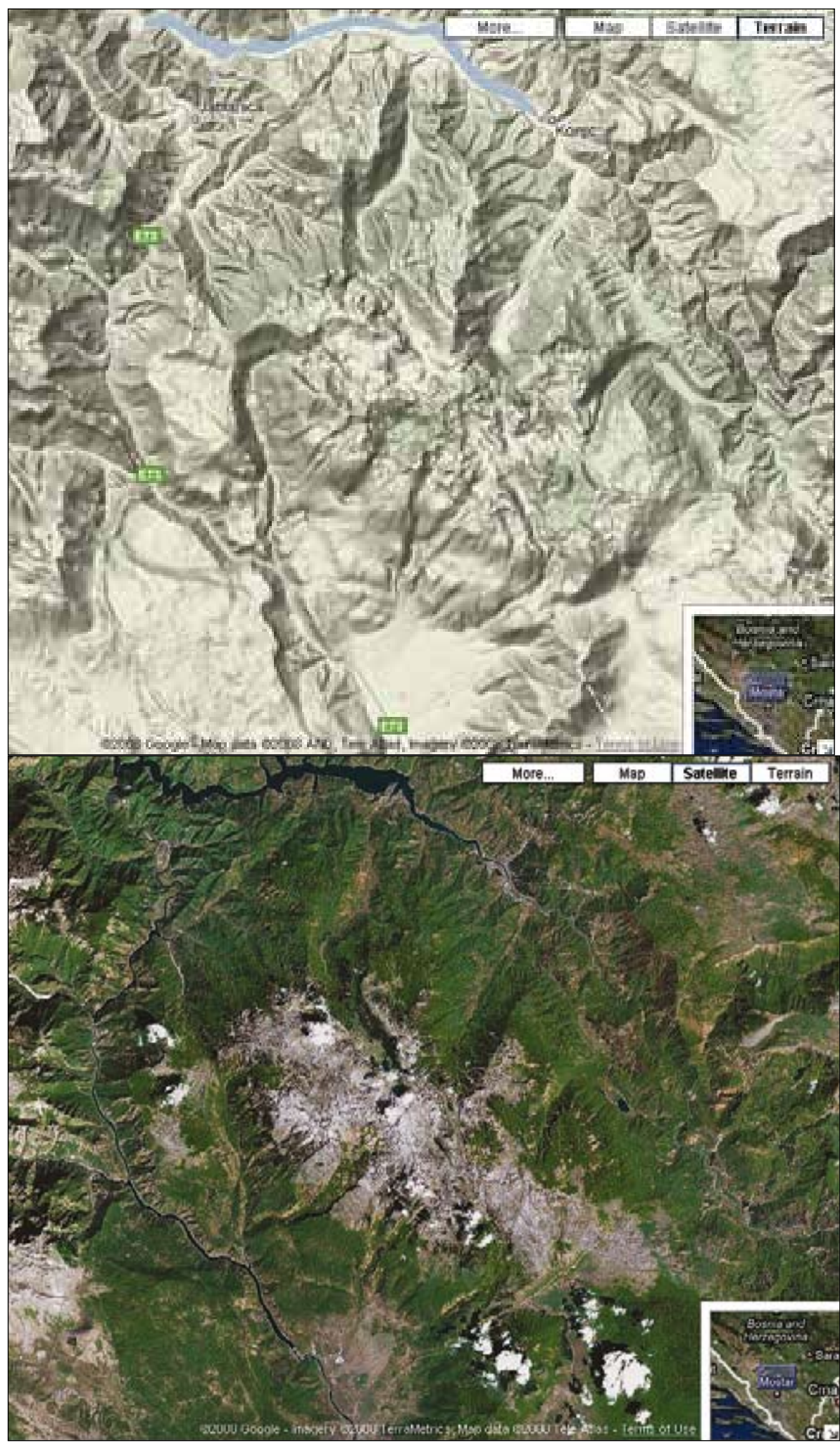

Fig. 2/2a: Digital elevation map (photo: Google Imagery/Map data).

ments: sandstones, marls, clays and sand limestone of the lower areas of the valley of Konjička Bijela and final northwest low slopes near Jablanica and Papratsko. Mid Triassic layers concordantly bed on them: limestones, breccied limestones, dolomites, volcanic - sediment formations (tuffs, cherts, hematitic schists) and igneous rocks (gabbro near the Jablanica, with small amounts of diabases in the valley of Konjička Bijela and granites in the zone of DrežničkoPorimska thrust).

Upper Triassic grey and dark gray dolomites with thin layers of limestone, are spatially most represented on the slopes of the northern and northeastern Prenj. On the ridges of Konjickka Bjelašnica and Borašnica, dolomites and limestones are markedly karstificated. Limestones have a large content of $\mathrm{CaCO}_{3}$ in the amount of 99.7\% (Mojičević \& Laušević 1973). Upper Triassic thick limestones with megalodons lithologically participate in composition of the highest slopes of Velika Kapa 2004 m a.s.l. and Osobac $2024 \mathrm{~m}$ a.s.l. and rocky escarpments of Cetina 1992 m a.s.l., Izgorjela Gruda 1878 m. a.s.l. etc.

Landforms of the central and southern part of the massif are shaped in subhorizontal, almost undisturbed layers of Jurassic limestones and dolomites. All three Jurassic periods are developed. Over low Jurassic, crypto-crystal and micro-crystal limestones, concordantly lay doger gray oolithic limestones with thin layers of dolomite limestone and dolomites. In them steep ridges and sharp peaks of Galić Prenj and Sivadija are shaped.

The highest positions, apart from the above mentioned, are represented by gray malm limestone with 


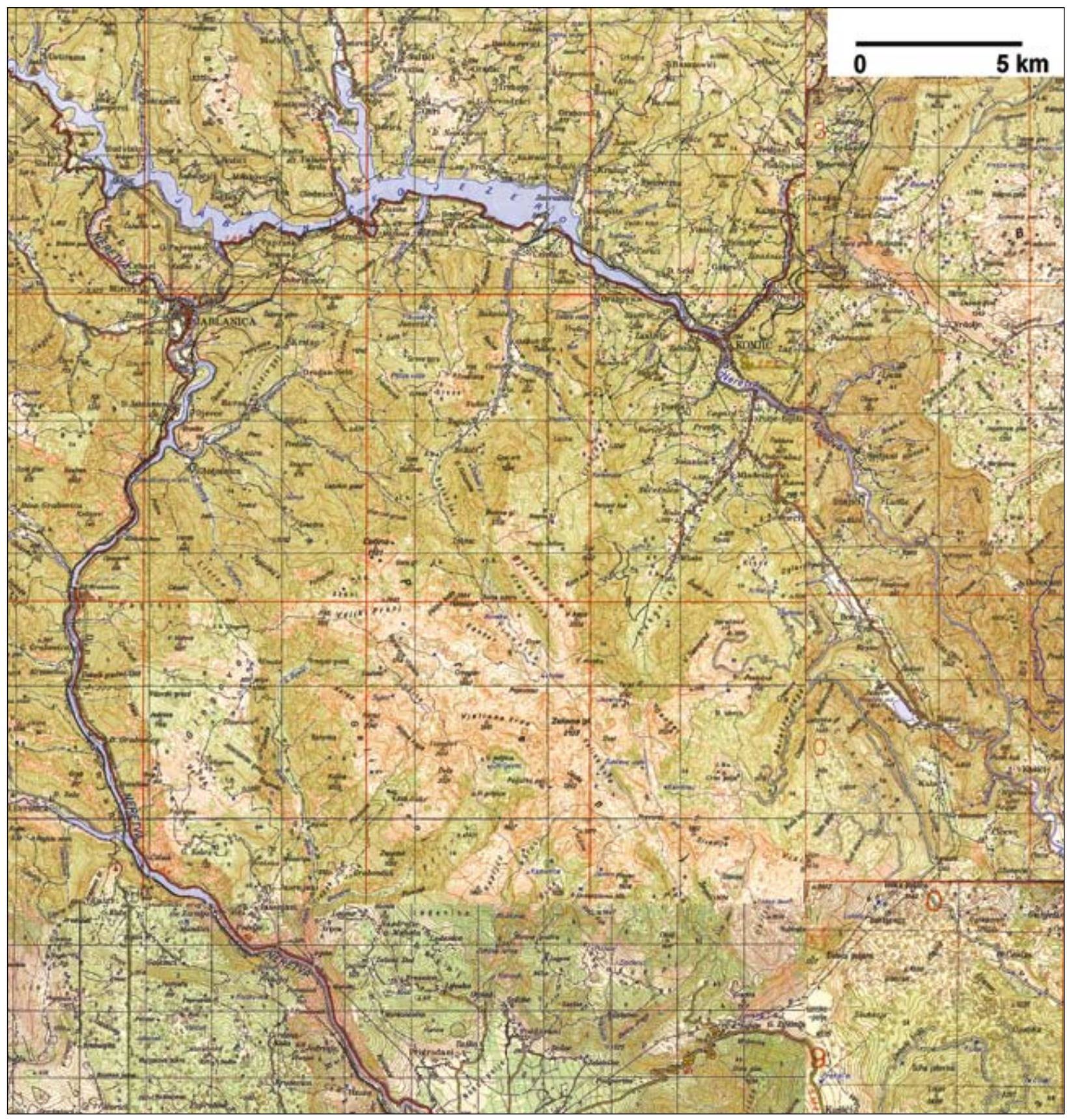

Fig. 3: Topographycal map.

cladocoropsis containing high percentage of $\mathrm{CaCO}_{3}$. Indissoluble residue is most often clay organic substance and less often quartz ( S. Čičić et al. 1984). In the composition of this part of terrain karstificated thick limestones resistant to egsogeomorphic processes are included. They are represented in the relief by the highest peaks Zelena glava and Otiš and arêtes Botini and Velika Kapljuč.

Thick deposits of Cretaceous limestones are lithologically dominant in the plateau Glogovo on the west.
Subhorizontal terrains of the mountain depressions, ending of the steep mountain slopes and valley morphosculptures are filled in with geologically youngest Quaternary deposits.

"Structural relations inside of Dinarides are very complex. Altitude differences in mountain systems are the consequence of uplifting, effect of differentiated erosion, filling of the local and regional basins with younger sediments, but also the previous secondary (tectonic) accumulation of certain rocky and struc- 


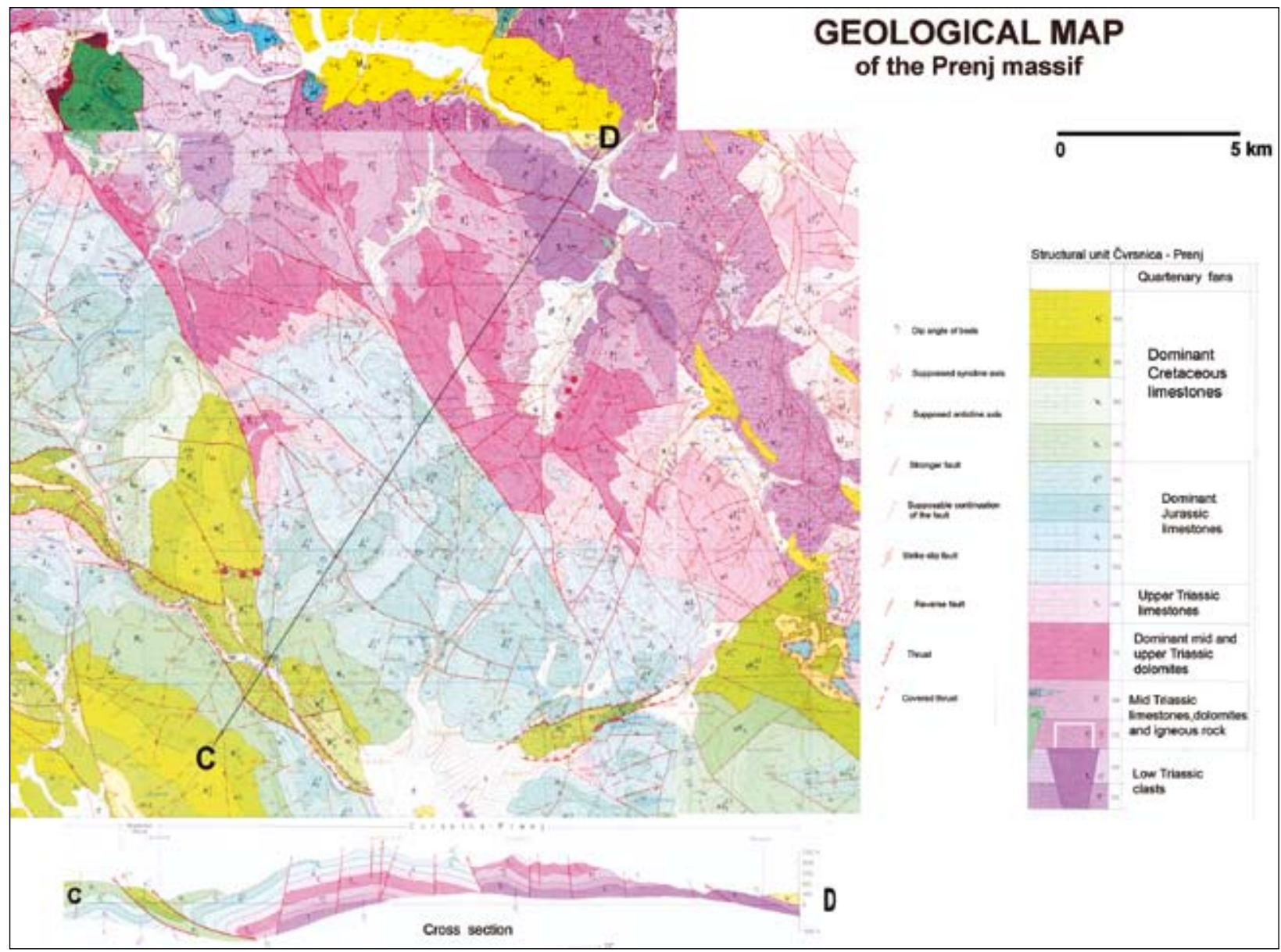

Fig. 4: Geological map.

tural complexes in the shape of napping and thrusting." (Herak 1983).

Upper Cretaceous folding which were in progress from the end of the upper Cretaceous were continues through Tertiary, when the further faulted lead to the development of depressions with a deposition of neogene sediments. By vertical movements at the end of Neogene and during Quaternary, the Herzegovinian massifs of Prenj (2103 m a.s.l.) and Čvrsnica (2228 m a.s.l.) were uplifted up to the present heights, as well as rectilinear ridges of Čabulja (1798 m a.s.l.) and Velež (1969 m a.s.l.). The above mentioned tectonic movements influenced on the genesis of the canyon of the river Neretva, and deep incised valleys of its tributaries which dissect these mountains.

From the morphostructural point of view, Prenj is a folded-thrusted mountain massif dating from pre-Tertiary and Tertiary folding.

The researched area enters into a composition of the structural unit Čvrsnica-Prenj which is a sub-unit of the Outer Dinarides. Diversity of geological structure of the massif can be seen in the occurrences of the folded layers, thrusts, faults, fault zones and tectonic windows. Due to the change in thrust stress caused by a rotation of the Adriatic micro-plate in neotectonic period, older faults were reactivated, with a Dinaric orientation NWSE. Moreover, the faults oriented E-W and the younger NE-SW and N-S were reactivated which lead to the micro-tectonic fissures of the researched area.

"The considered are is structurally expressed by three blocks mutually separated with two main Prenj faults (Fig. 4). They are: block Idbar, Bijela, Sivadija and then block Jablanica - Prenj and block Plasa - Jasenjanski gvozd" (Mojičević \& Laušević 1973).

Block Idbar, Bijela, Sivadija encompasses northern and northeastern part of the massif. It represents a structure of carbonate development which is with a regional thrust in the north partially thrusted and separated from the structures of the Central Bosnian Paleozoic. Its higher parts are represented by the gently folded mid-Triassic and Upper - Triassic dolomites and limestones with the angles of dipping layers lower than $30^{\circ}$.

Apart from the numerous reverse and normal faults of the short lengths and different orientation courses in 
the relief of this block, three local faults are prominent. The fault in a direction of the peak of Velika Kapa - valley of Idbar is oriented in a direction NNW-SSE. Then, the fault Bijele vode - valley Konjička Bijela - valley of Neretva river which in the fault zone Rakov laz changes its direction from a dominant direction N-S in to NNESSW. Northeastern part of the massif, in a direction of Sivadija- Borackka draga, is cut by the fault line oriented NE-SW.

The first main Prenj fault is a structural-lithological border toward the neighboring block Jablanica - Prenj. Its paraclasa tectonically separates Triassic, in the northeast, from the Jurassic formation in the southwest. It crosses the center of the massif with the length longer than $20 \mathrm{~km}$. It is oriented in a direction NW-SE, and it stretches in route: Vilin klanac - Bijele vode - PodotišTisovica - Rječice. The fault changes from place to place. In the northwest and partially in the central part of the structure reverse component of uplifting (reverse fault) predominates. In the southeast is marked by the horizontal movement of fault wings (strike-slip fault) which influenced on rotation of the block Idbar, Bijela, Sivadija. In the fault zone of Bijele vode where the first main fault crosses with two local faults, it is formed a tectonic window with Triassic layers.

Block Jablanica - Prenj is mildly folded carbonate plate of Jurassic rocks of the high central and south part of Prenj. It is micro-tectonically fissured by the numerous local short faults and fault zones, of different directions of stretching.
More prominent are two fault lines, around $10 \mathrm{~km}$ of length, with a dominant stretching direction NW-SE. One of them is a reverse fault, which cuts the central part of the block in a direction: Veliki Prenj - Lučine-peak Lupoglav - Poljice - Zaušlje and normal fault which stretches on the southwest from Vilina mountain to Rive.

In the south, gently inclined Jurassic layers are sharply cut with Drežničko - Porimska thrust. During the neotectonic phase of development of the massif, over its thrust plane Jurassic and Cretaceous sediments of Prenj were thrusted over Eocene and Upper Cretaceous layers.

Third Prenj block is represented by the plateau Glogovo, which morphologically belongs to west Prenj. It is separated by faults in the valleys of Neretva and Grabovka from the west and Porimsko - Drežnička thrust from the south and southwest. It is separated from the block Jablanica - Prenj with the second main Prenj fault, over $15 \mathrm{~km}$ long. The fault is oriented in a direction NNW-SSE and it cuts the massif in direction: valley Mostarska Bijela - Glogovo - Donja Jablanica. It is of similar kinematic as the first main Prenj fault. In the northwest it has reverse characteristics. In the central and southeast part of stretching it is characterized by the horizontal movements of wings (strike-slip fault), which caused a rotation of the block Jablanica - Prenj in the northeast. Together with faults in the neighboring valleys of Neretva and Grabovka, it influenced the rotation of the block Glogovo. This was reflected in a relief by elbow like turn of the valley Neretva from Drežnica to Bijelo polje from a direction N-S to direction of NW-SE.

\section{MORPHOLOGIC CHARACTERISTICS OF THE MASSIF}

From the morphological aspect Prenj represents mountain massif. Its dynamic relief plastic is expressed by mountain ridges of different directions of stretching (Fig. 2 and 2a). They are uplifted very steep above gently inclined surfaces of karst plateau Glogovo, uvalas and deep incised valleys and basins. The levels of planationpediments are of micro-location character, shaped on the edges of the massif.

Predominating limestone-dolomite composition of terrain and the intensive effect of neotectonic and egsogeomorphic processes have influenced on development of reticular structure of relief, which is expressed by the frequent change of relief mounts and depressions in the relatively short distances.

The analyzed area is characterized by hypsometrical complexity and very dissected relief. The local erosion base is presented by the river bed Neretva. Altitude difference between the highest and the lowest point in the researched area is $2008 \mathrm{~m}$ (river bed Neretva $\mathrm{m}$ a.s.l. near Salakovac and the highest point of Prenj - Zelena glava (2103 $\mathrm{m}$ a.s.l.). After conducted quantitative analysis of the relief according to hypsometric levels on topographic maps scale 1:25 000, it is determined that the most represented are high mountain belts higher than $1500 \mathrm{~m}$ a.s.l. They include around $140 \mathrm{~km}^{2}$ of the surface. (Fig. 5).

Average relative relief, which varies from 400 $800 \mathrm{~m} / \mathrm{km}^{2}$, is a basic morphological feature of the massif. Prenj, along with the neighboring massif Čvrsnica, is characterized by the highest values of the relative relief in this part of Dinarides, with the highest value up to $975 \mathrm{~m} / \mathrm{km}^{2}$. It is a part of northern escarpments Cetina (1991 m a. s. 1.) in the northwest part of high Prenj (Fig. 6). 


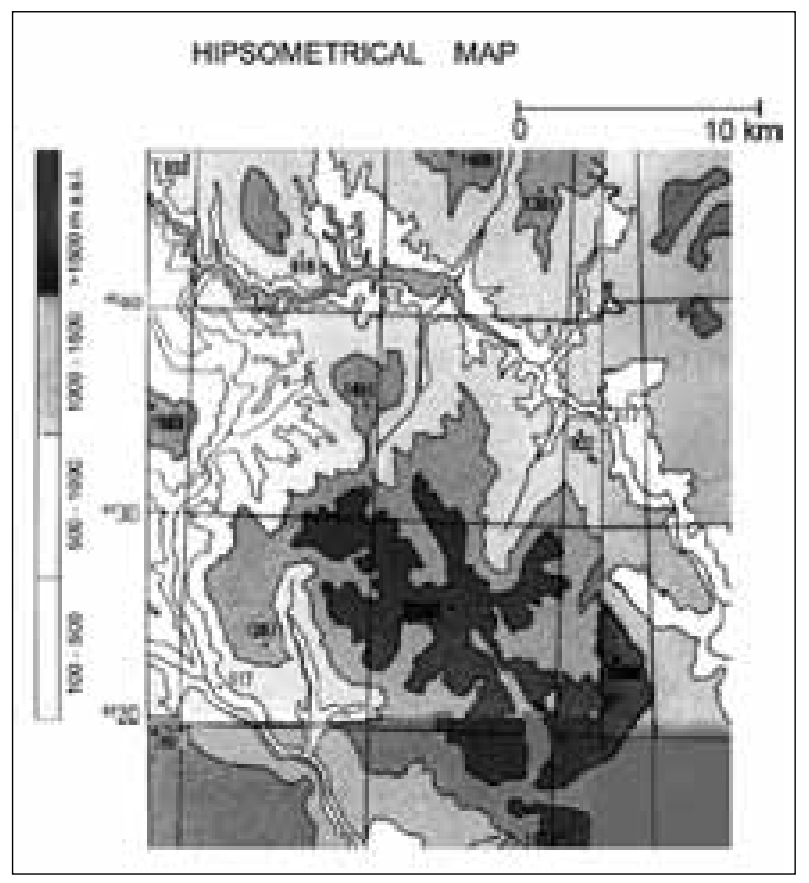

Fig. 5: Hipsometrical map.

Very dissected terrains are prevailing in the highest parts of the central Prenj and in the final west part of the massif. The steep slope fans are predominantly convex, which is a reflection of the neotectonic uplifting. Their angles of inclination are higher than $33^{\circ}$ edge the massif from the west and north. Kilometer escarpments with the inclination angle higher than $55^{\circ}$, whose relative heights are over $300 \mathrm{~m}$, can often be seen. They are perpendicularly directed toward subhorizontal terrains of karst denudational planes, pediments and deep incised low river valleys, with average inclination from $2^{\circ}$ to $9^{\circ}$. That is why they are characterized by the strongly expressed destructive-erosional processes. Eastern and southern slopes are less steep, with the average inclination of $20^{\circ}-30^{\circ}$. Due to the often and sudden changes of subvertical escarpments and scars with the convex, oblique slopes and smaller level of planation, asymmetrical transversal profiles dominate.

The important influence on inclinations of slopes of the massif has had fault neotectonic, carbonate lithological structure and paleo and recent geomorphic processes, exposition of slopes and vegetation cover.

Morphological structures are neotectonic, rectilinear and half-arc elongated. They have different stretching directions.

The most prominent orographical structures are the main top lines of mountain ridges. They are rugged with cols. The lower secondary ridges branch off from them, and they are marked by a development of steep slopes of fan-radial stretching and fault escarpments. Junctions of the main orographic axis are the highest peaks toward which the ridges converge. Three high mountain ridges crests converge the pyramidal peak Lupoglav (Fig. 7): ridge Vjetrena Brda - Erać from the north, ridge Vidina Kapa from the west and the ridge that connects it to Ovča in the south. The ridge with the highest peaks - Zelena glava and Otiš is peripherally separated, around $1 \mathrm{~km}$ to the northeast from the main orographic line. This "fish bone" Alpine orography marks the highest terrains.

Specific morphology of the highest sites of Prenj in comparison to the other neighboring Dinaric mountain

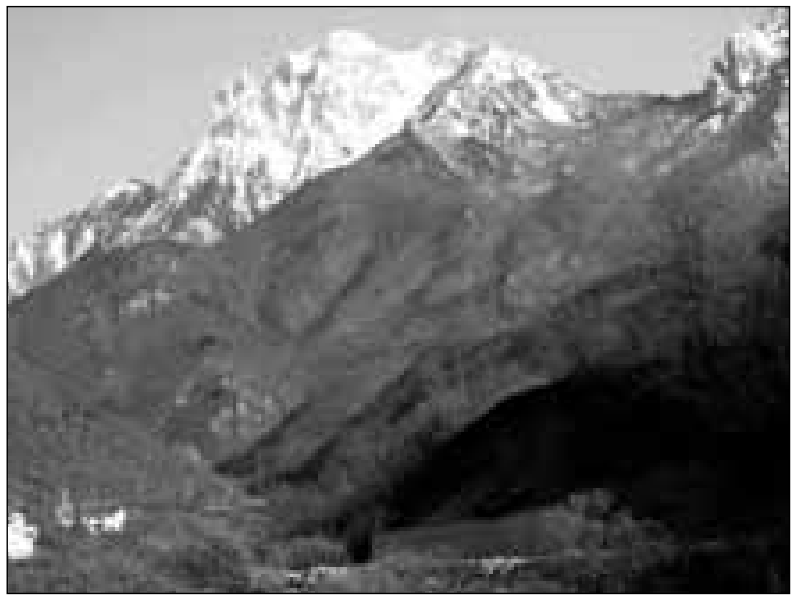

Fig. 6: Nothern escarpments of the peak Cetina (1991m a.s.l.) in April. View from the valley of Glogošnica river (photo: A. Lepirica).

morphostructure can be explained with the influences of the fault neotectonic, glacial, periglacial and mass wasting processes in jointed Jurassic carbonates.

In the central part of the massif, the most prominent is the highest mountain asymmetric ridge crest with sharp rocky peaks: Otiš (2097 m a.s.l.), Zelena Glava (2103 m a.s.l.), Erać (2035 m a.s.l.), Lupoglav (2102 m a.s.l.), Vidina kapa (2032 m a.s.l.), Ovča (2021 m. a.s.l.) etc. It is steep and narrow relief structure, which in the altitude range $400-600 \mathrm{~m}$ is steeply uplifted above the surrounding uvalas. It is half-arc elongated to around $12 \mathrm{~km}$. It is stretched in the route: Galić Prenj $(2042 \mathrm{~m}$ a.s.l.) - Vjetrena brda (2000 $\mathrm{m}$ a.s.l.) in a direction WNW-ESE, and at the peak of Botina (2074 $\mathrm{m}$ a.s.l.) it sharply turns in a direction NNW-SSE toward Velike Vršine (1971 m a.s.l.). This mentioned main orographic structure is separated from the neighboring ridges by the mountain uvalas shaped in the holokarst of high Prenj.

Less prominent in high mountain relief are halfarc outstretched ridges of Veliki Prenj (1915 m a.s.l) and Cetina (1991 m a.s.l.) in the northwest and Plavac (1924 m a.s.l.) in the southeast and Kantar (1883 m a.s.l) in the north of the central high Prenj. 


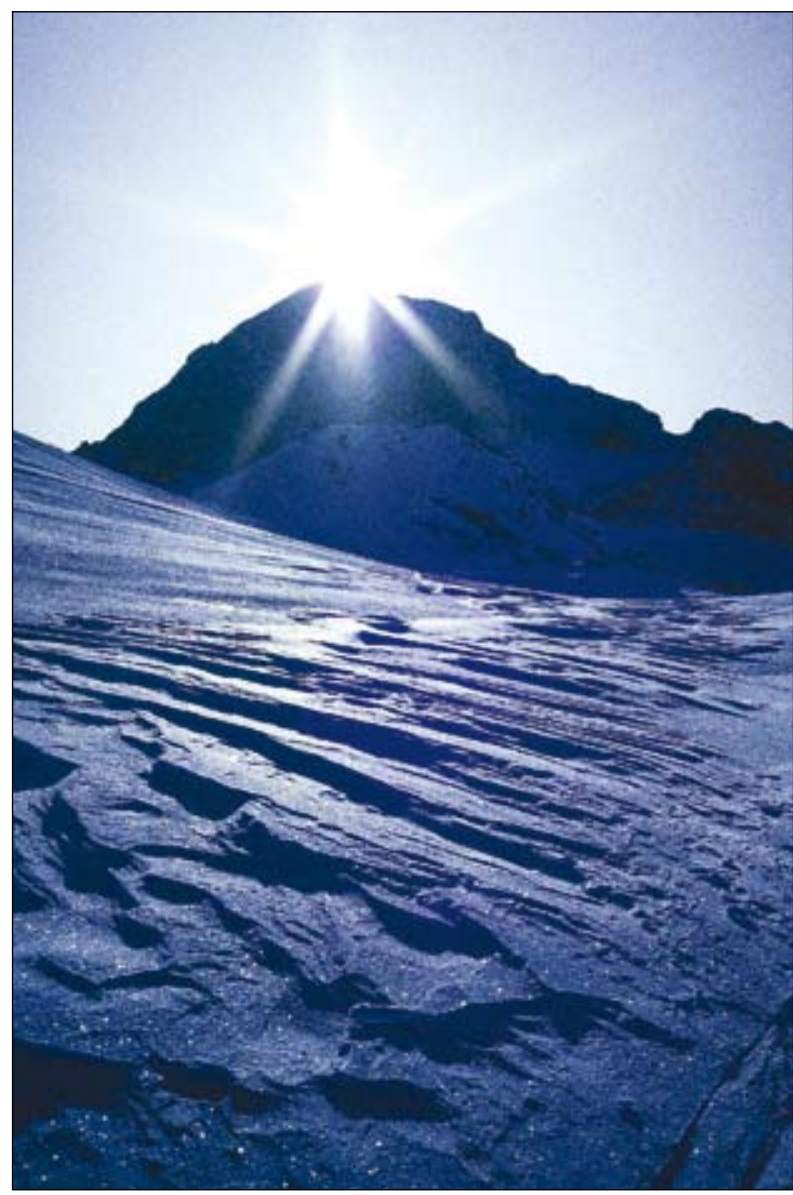

Fig. 7: Typical example of horn peak is Lupoglav, surrounded from three sides by deeply incised cirques of Lučine, Poljice and Barni do (photo: A. Lepirica).

The main orographic lines of the ridges Sivadija (1967 $\mathrm{m}$ a.s.l.) and Visin (1842 $\mathrm{m}$ a.s.l.) in the southeast are stretched in the direction E-W. Subvertical north escarpments are shaped within them.

Northeastern from the first main Prenj fault, ridges change their directions and height. The main orogrpahical axis of Bjelašnica ( $2004 \mathrm{~m}$ a.s.l.) is of NNW-SSE vergence, ridge of Rječica (1450 m a.s.l.) N-S and Ljubina (1247 m a.s.l.) NW-SE.

Pediments of Kiser, Ljubina and Sirova gora periclinally bed in the northern, and pediments of Rošca mountain bed the southern slopes of Prenj. The surface of their subhorizontal planes, with the average inclination between $5^{\circ}-9^{\circ}$, does not exceed $1 \mathrm{~km}^{2}$. They are developed at 1150-1250 $\mathrm{m}$ a.s.l. Lower pediments are spatially smaller. They are shaped in two altitude levels, in Cretaceous karst of the south-western part of the massif. The lower levels are represented by the pediments of Ravni and Grabovčić at the altitudes of 550-600 m, and average inclinations between $6^{\circ}-9^{\circ}$. The second level at around $750 \mathrm{~m}$ a.s.l. is morphologically expressed by ped-

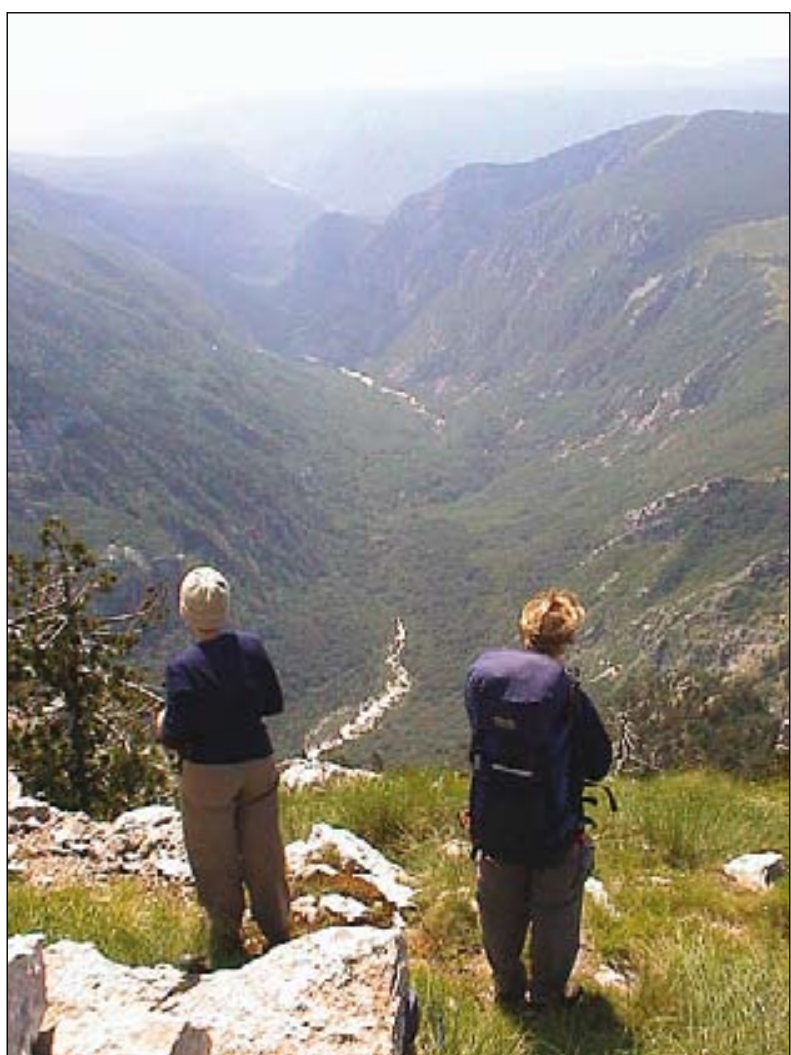

Fig. 8: The view on the valley of Mostarska Bijela from ridge of the Veliki Prenj (photo: T. Joubert).

iments of Gornje Selo and higher level of Ravni. They are of approximately same average inclinations of around $6^{\circ}$.

Karst plateau Glogovo in the west is a rectangular structure stretching in a direction N-S. It is $5.5 \mathrm{~km}$ long with average width of $3-3.5 \mathrm{~km}$. With its subvertical fault escarpments, over $700 \mathrm{~m}$ high, it is steeply ascended over valley morphostructures of Glogošnica, Mostarska Bijela and Neretva. It descends in the northwest in cascades. It is morphologically connected with Prenj complex in the northeast with narrow and steep, very dissected secondary ridge of Veliki Prenj. The average altitude of Glogovo plateau, shaped in Cretaceous karst, vary in the range between 1050-1150 m. At the edges of its gently wavy surface rise half-arc buckled ridges of Vidova (1451 m a. s. 1.) and Varda (1242 m a.s.l.) in the south. The relief of the plateau is expressed by the mutually connected system of the mountain uvalas: Vidovski gvozd, Stajski gvozd and Vilin čair. In structural-lithological sense, Glogovo is a south-eastern part of common block together with Plasa in the neighbouring massif Čvrsnica. The above mentioned points out the former orographical unity of Prenj and Čvrsnica as a part of the former carbonate plate. By the distinct deep incision of Neretva during neotectonic uplifting two independent Herzegovinian massifs were separated and formed. 
Deep inner mountain basin of Boračko jezero (404 $\mathrm{m}$ a.s.l.) is framed from the southwest with steeply ending northeast slopes of Prenj. Depression is of elongated shape and it stretches in a direction NW-SE. It is $2.7 \mathrm{~km}$ long with the average width of $0.5 \mathrm{~km}$. It is developed in the contact of regional structural units. It is assumed that it resulted from the movements of extension and tectonic subsidence in fault zone, during neotectonic period of development of Dinarides. Flat bottom of this inner-mountain depression presents local accumulation zone of Quaternary drifts over dozen meters thick. In the southeast it is filled with $13 \mathrm{~m}$ deep lake Boračko jezero (surface accumulation is around $0.25 \mathrm{~km}^{2}$ with the average water volume of $2500 \mathrm{~m}^{3}$ ).
The lowest positions (95-278 $\mathrm{m}$ a.s.l.) are expressed in a relief by inter-mountain depression of composite valley of Neretva river in the lengths of about 50 $\mathrm{km}$. It morphologically separates Prenj from mountain morphostructures Bokševica $1315 \mathrm{~m}$ a.s.l. in the north, Čvrsnica $2228 \mathrm{~m}$ a.s.l. in the west and Čabulja $1798 \mathrm{~m}$ a.s.l. in the southwest.

Linear elongated inner-mountain low valleys: Konjička Bijela, Idbar, Mostarska Bijela and Glogošnica are stretched up to $11 \mathrm{~km}$ of length. Valley bottoms are developed in the altitudes between $140-600 \mathrm{~m}$ a.s.l. Their upper - source parts are over $1000 \mathrm{~m}$ deep incised in morphostructure of Prenj (Fig. 8).

\section{RELATION BETWEEN RELIEF AND GEOLOGICAL STRUCTURE}

Prenj is denudational - tectonic morphostructure of Euro-Asian mountain chain system. In structural - genetic sense it represents folded-thrusted mountain massif of the Alpine orogen. Recent development of the massif relief should be regarded in the light of neotectonic uplifting (Pliocene-Quaternary) caused by collided microAdriatic plate and Dinaric carbonate plate. The landforms conform to geological structure in the spatially smaller localities of the researched area. This refers to smaller mounts and depressions shaped next to anticlinal and synclinal structures in the north (Bjelašnica, Ljubina) as well as to southern slopes of the massif shaped on the gently dipping Jurassic layers.

Reticular structure of the relief of the high central Prenj is discordant in relation to subhorizontal layers of Jurassic limestones and dolomites. Steep slopes and escarpments of the north and northeast part of the mountain with its bigger part of its stretching are developed in subhorizontal Triassic carbonates. Generally taken, Prenj is unconform structure because it relief is unconformable with the stretching of folded structures. Recent directions of stretching of the ridges, uvalas and valleys are determined here by the younger fault movements.

Drežničko - Porimska thrust from the south and southwest and thrust of the regional character in northeast structurally express neotectonic and relief border of this mountain with extension valleys and Tertiary basins in its periphery.

With the reverse faulting of the first main Prenj fault the following landforms are uplifted: the highest peaks of Otiš and Zelena glava, ridges of Kantar, escarpments of Cetina and Rječica. Along its paraclase the longest sys- tems of mountain uvalas are developed and shaped: Veline bare - Barice - Bijele vode and uvala Tisovica.

The second main Prenj fault predisposed the development of deep incised valley of Mostarska Bijela and surrounding escarpments. With the mid part of this dislocation, subhorizontal terrains of Glogovo are sharply separated from the steep western slopes of Veliki Prenj. By the reverse uplifting of its northwest wing high plateaus Glogovo and Plasa are uplifted. Faulting influences on elbow like turns of the valleys of the river Neretva (down stream of Donja Jablanica) and Mostarska Bijela (in the upper valley). Paraclase of the second main Prenj fault in the northwest expresses the structural, lithological and morphological border of the zone of intensive neotectonic uplifting of blocks of Prenj and Čvrsnica with inter-mountain depressions of the neighborhood of the town of Jablanica.

The main fault structures caused the rotation of Prenj blocks which was reflected on different orientations of stretching of the mountain ridges. The block of the high central Prenj is marked by predominantly halfarc and rectilinear directions of the main ridges oriented in WNW-ESE and E-W. Directions of stretching N-S and NNW-SSE are more rare and shorter. In the block that includes north-eastern parts of the massif, in the highest ridges orientations NNW-SSE, NW-SE and N-S dominate. Rotation of the blocks is reflected in directions of stretching of linear structures- valleys. The main valley of Neretva from the northwest, west and southwest bypasses the massif in half-arc way. Within the frame of the circular Prenj morphostructure almost uniform change of the orientation of river valley stretching can be noticed, as numbers on the clock because slightly rotation. 
The lower valley of Glogošnica in the northwest hanging valleys of its tributaries Bijela and Šanica are stretched in a direction of SE-NW. In the north, the valley of Idbar is stretched in gentle half-arc in approximate direction S-N. Then, the valley of Konjička Bijela is oriented in SSW-NNE, and the neighboring Boračka draga in the northeast is oriented in a direction of SSW-NNE. Kljenova draga in the south is stretched in a direction N-S, and the valley Mostarska Bijela is mainly oriented in a direction of stretching N-S.

Micro-tectonic fissures of central Prenj block is expressed by the relative dense net of the smaller local faults and fault zones. Western and central part of the highest ridge of Prenj is uplifted by local reverse fault which is stretched in a direction: Veliki Prenj- Lučine, peak Lupoglav- Poljice- Zaušlje. By the mentioned dislocation the following ridges are uplifted: Veliki Prenj, high mountain ridge with serrated peaks Kerać, Lupoglav, Erać, Ovča and tectonically predisposed uvalas of Lučina and Poljica.

After the conducted morphometrical and morphostructural analysis and comparison with basic geological map (scale 1:100 000) it has been determined that the escarpments of the highest peaks (Herać $2042 \mathrm{~m}$ a.s.l., Lupoglav 2102 m a.s.l., Erać 2035 m a.s.l., Ovča 2021 m a.s.l., Otiš 2097 m a.s.l., Velika Kapa 2004 m a.s.l., Osobac 2024 m a.s.l., and peak Sivadija 1967 m a.s.l.) which directly incline toward fault structures have the average values of relative relief higher than $500 \mathrm{~m} / \mathrm{km}^{2}$.

Narrow and high cols of the central and northeastern part of Prenj are transected by local fault lines. These fault predisposed micro-relief forms are shaped between peaks of Galić Prenj, Vjetrena brda, Botin, Zelena glava, Otiš and Sivadija. Similar morphotectonical features have high cols between the highest peaks of the northern and northeastern Prenj: Velika Kapa, Kruna, Motika and Taraš.

By the fault in direction peak Velika Kapa- valley Idbar in the north part, uvalas Rapta and Pasje doline are tectonically predisposed. In the northeast Prenj along the fault Bijele vode- valley of Konjička Bijela- valley of Neretva the following landforms are shaped: uvalas of Vlasni dol and Dolovi, escarpments Skok and peak Osobac, and the river valley of Konjička Bijela.

The fault Sivadjia - Boračka draga fissures eastern and final northeast part of Prenj. Along its paraclase deep incised, derasional valley Boračka draga was developed.

Steep slope fans are cut by the long gullies, over 1.5 $\mathrm{km}$ long, developed next to local faults.

Local fault zones have influenced on the change of directions of the ridges, as it is the case with sharp turns of direction of the highest mountain ridge crest in direction: Vjetrena brda - Botini - Velike Vršine and Lupoglav - Erać - Vjetrena brda.

Relief depressions of the source parts of valleys Konjička bijela, Idbar, Mostarska Bijela are formed in tectonically fissured fault zones. Fault crossings are favorable to the intensive karstification process of Mesozoic carbonates and development of pitted karst as for example in the local fault zones of Zaušlje and Stanine in high Prenj with a great abundance of dolines $\left(>40 / \mathrm{km}^{2}\right)$.

Composite valleys of Neretva, Mostarska Bijela, Idbar, and Glogošnica are obsequent transversal valleys whose stretching directions are controlled by faults. Wider parts of the valleys are structurally presented by the local fault zones.

Fluviokarstic gorge of Bijela, left tributary of Glogošnica is developed next longitudinal fault.

\section{MORPHOGENETICAL TYPES OF RELIEF}

Various endogenous and egsogenous factors (low temperatures, ice, snow, sheet wash, strong winds bura and jugo etc.) have influenced on development and recent dynamics of Prenj relief. From morphogenetical point of view, here are represented: slope, karstic, glaciokarstic, glacio-fluviokarstic, glaciofluvial, periglacial, fluviodenudational, fluvial, fluviokarstic erosional and accumulation landforms. In the lower areas and narrow zones of the massif, anthropogene relief is also represented.

\section{SLOPE PROCESSES AND LANDFORMS}

Neotectonic uplifting and intensive egsogeomorphological reshaping of the considered Herzegovinian karst massif have primarily influenced on the current position and geomorphological characteristics of slopes. They are morphogenetically marked by a wide spectre of active denudational destructive processes: mass movements, erosion, corrosion, cryogenic etc. which are reflected by the different movements of earth materials and high rates of mass wasting. Cascade profiles dominate due to often occurrence of relief bends expressed by escarpments and pediments. Mostly represented are the convex and oblique slopes with active derasional gravitational processes: rock falls, debris flow, snow avalanches and torrents. Gently inclined mountain slopes are marked with the periodical periglacial creep of rock fragments and soils and 
karst corrosion. Mountain footslopes on the north and west are shaped by fluviodenudational, fluviokarstic and fluvial processes.

Steep mountain fans are dissected by erosional forms of mountain gullies and dragas. Due to the dominating gravitational processes of debris avalanches and debris flow, mountain gullies are filled with massive, unsorted and not rounded debris. The longest gullies of Prenj over $1.5 \mathrm{~km}$ in length are linear incised in steep slopes which directly connect upper parts of Prenj ridges with the upper valleys: Konjička Bijela, Mostarska Bijela, Idbar, Draganska rijeka, Jarmata and Bijela. During the spring when snow melts and in the rainy period in the fall through them flow torrents, coming down in waterfalls and cascades, that are sometimes over $50 \mathrm{~m}$ tall. The mentioned relates to periodical waterfalls: in canyon sides of Neretva, Skok in the slopes above Konjička Bijela, Jarmate above Glogošnica, in the valley sides of Mostarska Bijela, Idbar etc. In spring and winter in the altitudes above $1400 \mathrm{~m}$ a.s.l. they have a function of snow avalanche corridors. Their endings in the contact with low subhorizontal valley planes are represented by cones accumulated in colluvial-prolluvial fans.

Polygenetic forms derasional valleys in deep Herzegovinian karst are called dragas. In the researched area the most prominent in the relief are: Boračka draga (5 $\mathrm{km}$ long) in the northeast, and Klenova (4.3 km long) and Velika draga ( $3 \mathrm{~km}$ long) in the south of the massif. Remaining dragas are shorter and less expressed in slope relief. They are predisponed by faults and denudationally shaped. They have a narrow bottom which is inclined in a direction of general fall of terrain. The average inclinations of longitudinal profiles of the mentioned Prenj draga are almost identical and have $9^{\circ}-9.5^{\circ}$. Their steep sides are often represented by subvertical rocky walls with the relative height of over $300 \mathrm{~m}$. In these locations the processes of rock falls are active so the bottoms and lowers parts of deeply incised hanging valleys are filled with taluses of subangular debris. In dragas the recent periodic prolluvial and solifluction processes are also represented.

Prominent in the relief, the landforms of fault escarpments are of several kilometres long with relative altitudes which are sometimes over $400 \mathrm{~m}$. The biggest subvertical rocky walls of Prenj are: Cetina, Izgorjela Gruda, western and eastern escarpments of Glogovo, Korita, Vilin Kuk, Otiš, Povezak, Zubac, Osobac, Velika Kapa, Sivadija, Crvenice, Narad, Herać etc.

They are predisponed by faults. Rock fall mass movements caused by the influence of rock weathering are dominantly geomorphologically marked. Deep beneath, in their basis there have been accumulated taluses of collapsed, unsorted, massive angular debris, a few kilometres long.

Bizarre slope forms karst towers, monoliths and karst windows resulted from destructive action of weathering processes along joints in limestones and dolomites and gravitational processes. "Weathering acts upon rocks to produce solid, colloidal and soluble materials. These materials differ in size and behaviour"(R. J. Huggett, 2003). In more resistant Upper Triassic limestone the following monoliths are shaped: Vidrine grude and Burin klis with the relative altitudes above $100 \mathrm{~m}$, then Djevojački kuk, Stog, Letokin grad etc. Numerous karst towers with over a few dozen meters in height are prominent in the relief in the slope area of the mountain and sub-mountain belt, and in the sides of deeply incised Neretva. The highest karst window is located in the slopes of Lupoglav at the altitudes above $2000 \mathrm{~m}$ a.s.l. The same micro-relief forms are developed in karst of the ridge crest of Osobac and Borovac in mid-mountain ridge Rječica. The most monumental karst window, not only in Prenj but wider, with dimensions of opening $20 \times 15 \mathrm{~m}$ is shaped in the escarpments of eastern Glogovo at around $800 \mathrm{~m}$ a.s.l.

Denudational - accumulation landform pediments of Kiser, Ljubina, Sirova gora are developed in northern, and Ravni, Jasenjani, Grabovčići and Rošce mountain in the southern bordering slopes of Prenj. They originated and were developed in three altitude levels, in pre Quaternary period, under the influence of areal slope processes in Mesozoic carbonates. Their gently inclined planes with the inclination of $6^{\circ}-9^{\circ}$ point to former periods of tectonical stability. They represent fragments of older level of planation.

Low slopes (lower than $800 \mathrm{~m}$ a.s.l.) near Ravni and Krstac in the northwest and Jošanica in the north are dissected by linear erosion due to impermeable constitution of terrain. Denudational processes of torrents prevail, which caused development of rills and gullies. At their end delluvial and prolluvial cones are shaped. Lower Triassic clasts are included in the lithological structure of slopes of northern bordering belt of the massif, which incline toward lake Jablaničko jezero, in a direction Jablanica-Papratsko-Ostrožac. Due to the involvement of clay particles destructive fluidal processes- landslides are active.

\section{KARST LANDFORMS}

Evolution of orogenetic karst of Prenj should be seen through a few phases of karstification. Older phases are related to the cycles of emersion of carbonate platform of Outer Dinarides (Upper Cretaceous bauxites near the Jasenjani). By the later neotectonic uplifting of the Herzegovinian mountain massif karst processes were intensi- 
fied (with the interruptions caused by cold glacial stadials) and it shaped recent relief of the area. Dominantly represented karstifed basis of thick Mesozoic carbonate sediments, with the altitude above $2000 \mathrm{~m}$ and relatively big amount of snow-rain precipitations (in average more than $2000 \mathrm{~mm} /$ year) carried by strong winds which resulted in prominent polymorphic karst relief forms.

Terrains, which are in average above $1500 \mathrm{~m}$ a.s.l., are characterized by high mountain karst with glaciokarst forms, partially reshaped by recent egsogeomorphological processes. In higher parts of the massif, high bare karst can often be found. Eastern, central and western parts of the massif are widely encompassed with polygonal karst of mountain uvalas. The lower areas are represented by subcutaneus karst below shallow bedded carbonate soils on which exist mixed woods.

Morphostructure of Prenj is characterized by the noted occurrence of landforms incurred by corrosional action of melted snow, ice melted and rain water on carbonate bottom, from microkarst grikes $(1 \mathrm{~cm}$ diameter) to karst denudational plains (diameter up to a few kilometers). Dissolutional sculptures of grikes of different shapes (reticular, bowl-shaped, ribbed) and depths (from a few $\mathrm{cm}$ up to a few meters) can be found along the entire massif. Often they form systems of karrenfields cut by grikes, which is especially expressed in

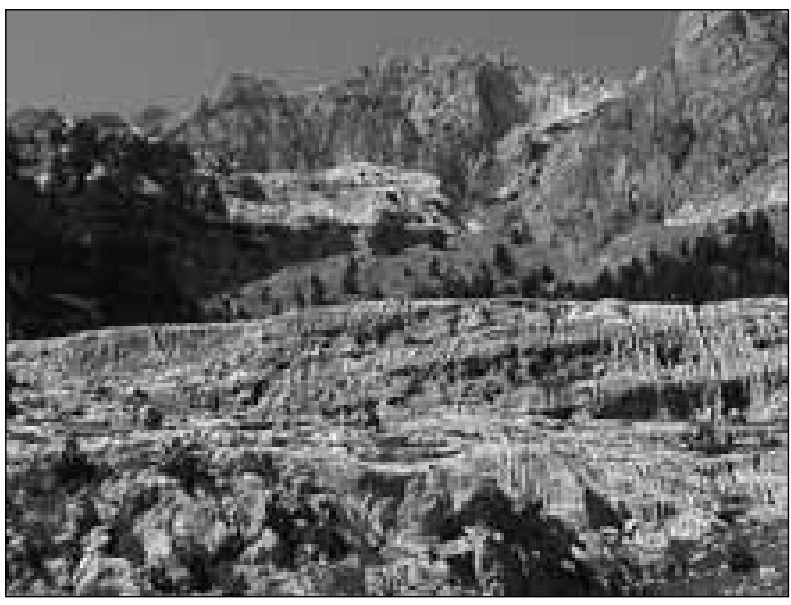

Fig. 9: Karren fields in the high mountain belt of Galic Prenj (photo: T. Joubert).

overgrown with Pinus mughi vegetation. Extreme density of the occurrence of these karst depressions we relate to subhorizontal terrains of mountain uvalas (Fig. 10). Sporadically they formed pitted karst, as in Glogovo, in karst denudational planes Vidovski gvozd and Vilin čair and in uvalas Rudo polje, Ruda lastva and Stanine in the east and southeast of Prenj (Tab. 1).

They are often predisponed by fault lines that are stretched in lower areas. They have different shapes: from shallow plate-like, bowl, cauldron, funnel-like to very steep and narrow. Usually, the average length of diameter is up to $50 \mathrm{~m}$, and around $20 \mathrm{~m}$ deep. It is not rare to find the bigger ones, as it is Meka vrtača in the northwest of Glogovo (diameter $130 \mathrm{~m}$, depth $35 \mathrm{~m}$ ) and other developed in subhorizontal terrains. „Solutional enlargement is either circular in plan, if there is one dominant vertical joint, or otherwise irregular if there are several and can achieve dimensions of up to 1000

higher areas of bare karst. Typical examples of karrenfields can be found in Zakantar, under Sivadija, in Galić Prenj, etc. (Fig. 9).

Eksokarst landforms - dolines are developed in wide altitude range, from Gornji Jasenjani at $450 \mathrm{~m}$ a.s.l. to upper parts of slopes of Herać at $1990 \mathrm{~m}$ a.s.l. The ones at the higher positions during glaciation had a role of cirques. In high mountain belt they are often meters in diameter and 100 meters deep" (Karst terminologies, 2002, 62).The two biggest Prenj dolines located in high karst of Zakantar, at the altitude of around 1550 $\mathrm{m}$ a.s.l. It has gently inclined sides, shaped by simultaneous influences of karst and periglacial processes. Diameter length of the bigger depression reaches $600 \mathrm{~m}$ with depths up to $60 \mathrm{~m}$. Smaller neighboring depression, located more toward east, has two times shorter diameter from the above mentioned. 


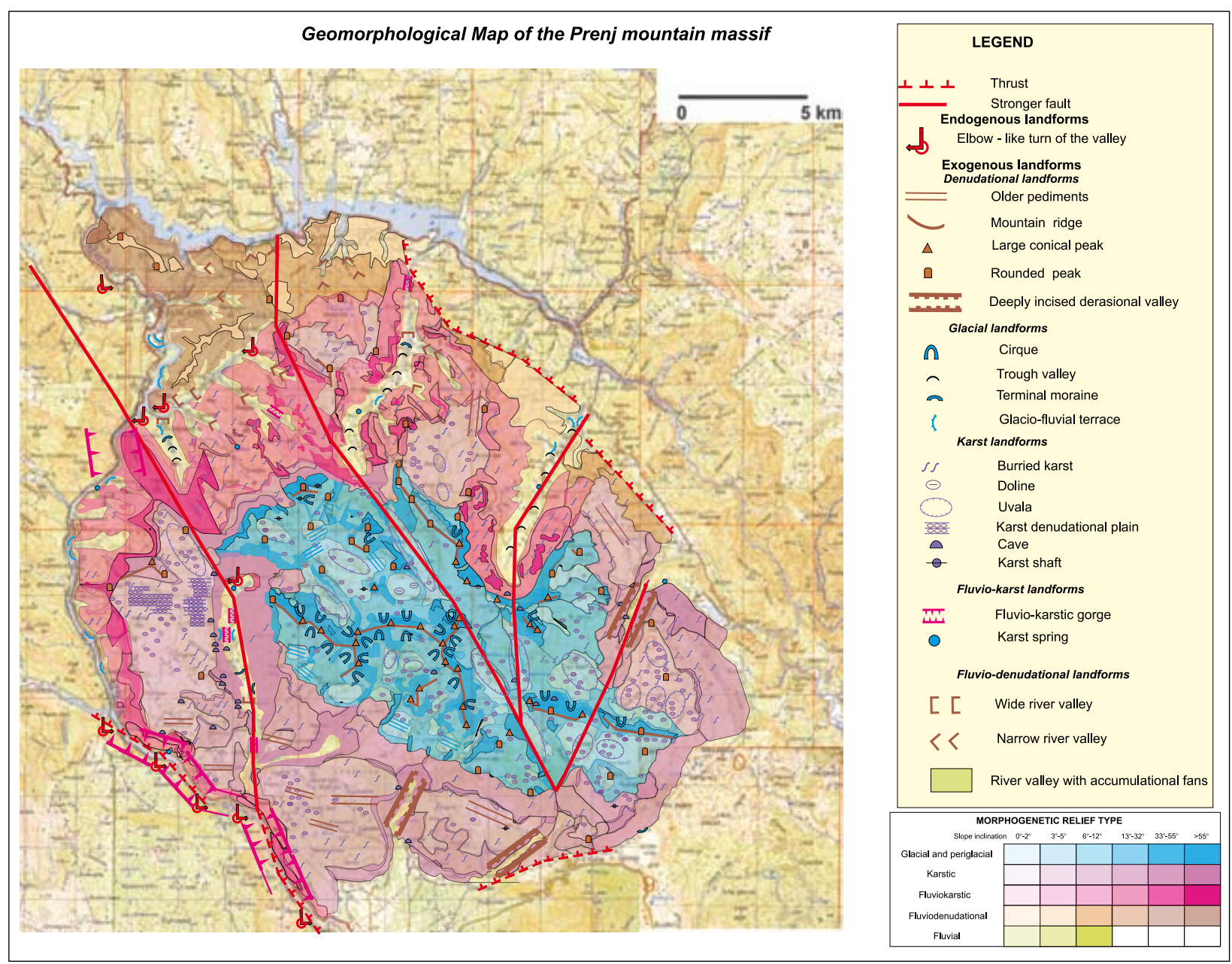

Fig. 10: Geomorphological map.

Elongated shapes of mountain uvalas are developed in holokarst of Prenj (Fig. 10). Tectonically are predisponed and polygenetically shaped by karstic, glacial erosion and periglacial geomorphic processes. The biggest landform is Tisovica, around $4 \mathrm{~km}$ long, and in several places wide over $500 \mathrm{~m}$. In the central part of the massif uvalas are connected in orographically closed systems, up to $8 \mathrm{~km}$ long. They are arranged in cascades on mountain tops, form the highest at $1650 \mathrm{~m}$ to the lowest at $1098 \mathrm{~m}$ a.s.l. They are mutually separated by smaller karstified mounts. Their bottoms and gently inclined sides are cut by dolines. Spatially biggest system of uvalas in Glogovo is: Stajski gvozd - Vilin Čair - Vidovski gvozd. The longest systems of high central Prenj is: Bijele Vode - Barice - Veline bare, Lučine (Klarića and Mršića dolovi), Vlasni do - Veliki do - Crno polje, Gladišta - Čemerikovi doci and uvala Tisovica. Eastern and southeastern parts of mountain are morphologically expressed by wide uvalas Rudo Polje, Javić and Razdolje at the altitudes of 1500$1650 \mathrm{~m}$. Those are areas dotted by dolines and separated from the high mountain ridges of Prenj in the west by a fault in a direction Sivadija - Boračka draga. Rounded peak of Obrlin orographically closes it from the south and north. In northern Prenj, the most expressed system in the relief is Pasje doline-Rapti. The rest have smaller surface than the mentioned. Often used synonym for uvalas in these areas are dolovi and vale. At the altitudes above $1500 \mathrm{~m}$ they are covered by the low vegetation of mountain pastures or completely bare and karstified.

Spatially biggest polygenetically karst denudational plains planes are located on the flattened top surface of the plateau Glogovo. Those are the areas of Vidovski gvozd and Vilin čair, which are marked by pitted karst (Fig. 10).

Caves and cave systems are shaped by corrosions along the fractures in epikarstic zone of the researched Herzegovinian massif. Their endokarstic subvertical openings are of different dimensions and position. They can be found from the lowest altitude levels in the gorge of Neretva to the top slopes of the highest ridges Osobac, Botina, Sivadija etc. So far they have not been researched by appropriate speleomorphological methods. 
In the eastern part of Prenj caves can be found in rocky walls of Crvenica, Sivadija, near Prevorac. In the northern slopes, there are caves along the lower stream of Idbar, in the escarpments of Rječica, Izgorjela gruda and in the other places. In Glogovo those are: cave systems of hanging positions in Vise, then caves Tmuša, Crna spila and Loparnica with the openings in the steep slopes (Fig. 10). In high central Prenj, we will mention-Poljička cave, in Kantar, a cave southern from Gruca, in Zaušlje etc. In the final southern slopes those are: Golubovica, Mehina spila and Hercegovača. On the finally west footslopes there are active caves with the springs Mlješčak and Crno vrelo which are sunk by artificial accumulations in the canyon of Neretva.

Rock shelters are smaller endokarstic forms widely represented in the researched area. They are shaped in rocky cliffs and the often appear in groups. One of the biggest rock shelter is located in the upper valley of Mostarska Bijela. Its $100 \mathrm{~m}$ half-arc elongated clasto-karstic landform, with the average height of around $8 \mathrm{~m}$, is developed in a scarp of conglomerate terrace.

Speleomorphological objects - shafts have not been researched. The people of this are call them: ledenice, zvekare, zvonuše, propasti etc. The ones located at the higher altitudes which preserve snow and water during the entire year used to serve as a water supply for people and cattle. Shafts that had that function are: below Crnoglav, between Cetina and Veliki Prenj, Golubinka in Rošce mountain in the south, below peak Čalopek in the southeast and others near shepherd seasonal settlements.

\section{HYDROGEOLOGICAL CHARACTERISTICS}

Tectonically fissured carbonate base influenced the genesis and development of ponors, underground channels systems and channels where water percolates into the karst underground of Prenj. The biggest part of the mountain area is waterless with rare springs, very small in quantities, which disappear in the ground very close to their sources. Such springs are: in Barni dol, Poljica and Sopot in Galić-Prenj, Gruca and Zaušlja, Vrutak, Novak and Zagon in Tisovica, Jezerca, Zubčeve vode, Kamenac and spring in Crno polje in the northeast part of the mountain and springs in Bijele vode, Kamenica and Jezero in the southeast of the massif. During the dry periods of the year, many of them dry out. Fissure ponors, as the ones in Jezerce or in Tisovica are significantly represented here.

The bottoms of the smaller closed karst depressions Jezerce (1640 m a.s.l.) and Jezero (1495 m a.s.l.) with bed of impermeable layers are filled with small and permanent karst lakes. During spring in lower Tisovica a periodical lake is formed due to the small capacity of the ponors which are at that time blocked by drifts.

According to topographical position of the bigger and permanent karst springs, the main privileged directions of underground flow are directed toward west and north. Quantitatively the biggest springs can be found in the lowest positions of the Neretva gorge in the far western foot of the mountain. Those are tectonically predisponed permanent springs Mlješčak and Crno vrelo with more than a few $\mathrm{m}^{3} / \mathrm{sec}$ of flow. Two and half decades ago they were sunk by artificial accumulations on Neretva. Left tributaries of Neretva: Konjička Bijela, Mostarska Bijela, Idbar and Šanica (component of Glogošnica) originate from karst springs with the average annual flow smaller than $1 \mathrm{~m}^{3} / \mathrm{sec}$. These springs are developed in the contact of Triassic limestone with less permeable dolomites in bed rocks, at the altitudes of 550-600 $\mathrm{m}$ a.s.l. (Fig. 10). In lower deep incised gorge of Mostarska Bijela, from subhorizontal narrow joint springs evenly come out in the length longer than $100 \mathrm{~m}$.

In river beds ponors of sieve type are active, as it is a case with Mostarska Bijela, which disappears a few times in its river bed during dry period of the year. It is most important to emphasize that in the area of Prenj there have not been any appropriate hydrological researches so far, and the text contains only what is noticed in the field.

\section{GLACIOKARSTIC RELIEF}

Neotectonic uplifting and climate conditions in colder periods of Pleistocene were suitable for development of glacial processes in Prenj. Development of former glaciers was significantly influenced by: altitudes of the massif, specific geographic position (non-existence of higher relief barriers from the south and north and exposition of moist air circulations) and reticular structure of paleokarst relief. High mountain glaciokarstic relief predominates at the altitudes above $1500 \mathrm{~m}$ a.s.l. It encompasses the surface of around $100 \mathrm{~km}^{2}$.

Although in some places completely of partially destructed and covered by recent geomorphic processes, fossil glaciokarstic landforms can be clearly recognized in the relief of the mountain area.

Arête, horn peaks and cols (Figu. 11 and 12) are shaped by glacial erosion, frost shattering and mass movements along subvertical joints and fracture systems. They were reshaped during Holocene by recent periglacial processes. The longest high mountain arête, developed in Jurassic limestone, is in half-arc extended along the central part of the massif in the length of around $12 \mathrm{~km}$. Residual landform horn peaks are shaped in it: Zelena glava $2103 \mathrm{~m}$ a.s.l., Otiš $2097 \mathrm{~m}$ a.s.l., Zečice 2015 m a.s.l., Lupoglav 2102 m a.s.l., Erać 2035 m a.s.l., 
Ovča $2021 \mathrm{~m}$ a.s.l., Vjetrena Brda $2000 \mathrm{~m}$ a.s.l. and Botini $2074 \mathrm{~m}$ a.s.l. In the close neighborhood of the highest Prenj arête there are located serrated peaks: Crnopoljski Osobac $1921 \mathrm{~m}$ a.s.l. and Crnoglav $1892 \mathrm{~m}$ a.s.l. Tops of the northeastern Prenj have similarly dominant relief forms: Osobac 2024 m a.s.l, Motika 1832 m a.s.l., Kruna $1914 \mathrm{~m}$ a.s.l., Zubci $1916 \mathrm{~m}$ a.s.l. and Taraš $1742 \mathrm{~m}$ a.s.l. and are developed in Upper Triassic dolomite and limestone.

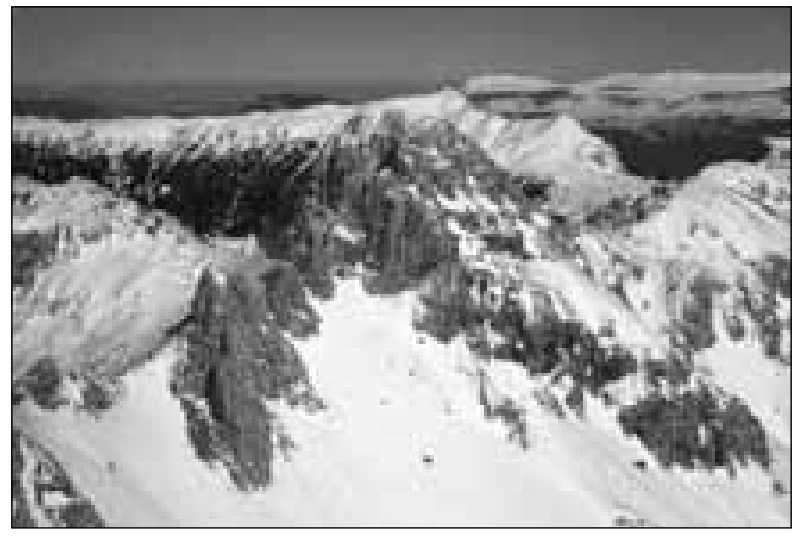

Fig. 11: View from the Lupoglav peak towards north - horn peak Erać shapped in a highest arête and ridgecrest of the Konjička Bjelašnica at background (photo: A. Lepirica).

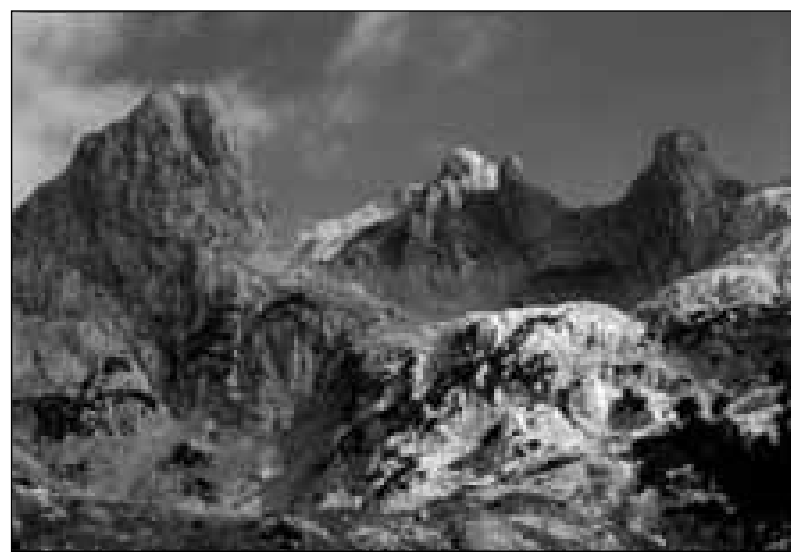

Fig. 12: The highest horn peaks of the Prenj massif: Otiš $2097 \mathrm{~m}$ left and Zelena glava $2103 \mathrm{~m}$ a.s.l. right with fossil cirques bellow (photo: A. Lepirica).

The most distinct example of pyramidal horn peak of this part of Dinarides is Lupoglav (Fig. 7). It is dissected from three sides by deep fossil cirques: Poljica from the east, Lučine in the northwest and Barni dol in the southwest. Neighboring peaks Erać and Ovča have similar forms.
Cirques are deeply incised in high mountain arêtes by glacial erosion. In their pits snow gathered and glaciers ice was developed. The main fossil cirques of Prenj are at the altitudes above $1500 \mathrm{~m}$ in: Barni do, Lučine (above peaks of Herać and Lupoglav), Poljica, Janjina, Gruda and Ovče draga (below peaks of Lupoglav and Ovča), Stajetine (southern from the peak Vidina kapa) upper Tisovica and Podotiš (below peaks of Zelena glava and Otiš), in the slopes of Vjetrena brda and Botini, in the northern slopes of Sivadija and Visin etc.(Fig. 10). In the recent time, due to the combined influences of periglacial and karstic processes they are filled in with talus. During the most intensive phase of the last larger glaciation, the lowest cirque zones were located at the altitudes of around 600-700 $\mathrm{m}$ a.s.l. At that time, depressions in the source parts of Prenj lower valleys - Rakov laz, Bukov laz, Prilipe and upper Kljenova and Velika draga were filled with ice of hanging glaciers which came down from high mountain belts.

During stadials many of the mountain uvalas and derasional valleys - dragas had a function of trough valleys. The processes of dragging, breaking and sliding of the ice mass over carbonate bed rocks happened here.

On the basis of field observation, the identification of landforms of glacial erosion and glacial deposition is made and their altitude position is determined. From the above mentioned it can be emphasized that during the maximum glaciation Prenj glaciers came down to low valleys.

The main directions of the ice flow in Prenj were:

1. Zakantar - Tisovica - valley of Idbar (U shapped profile).

2. Fossil trough Lučine (U shapped profile) - valley of Mostarska Bijela (U shapped profile).

3. Vlasni do - Crno polje - Boračka draga - basin Boračko jezero.

4. Slopes of northeast Prenj - Rakov laz - valley Konjička Bijela (U shapped profile).

5. System of fossil trough: Veline Bare - Bijele vode - Dolovi - Kruševac - Velika draga.

6. Stajetine - Konjedol - valley of Mostarska Bijela

7. Poljica - Pritres.

8. Zaušlje - Gruci - Kljenova draga.

9. Ruževača - Hansko polje.

Roche moutonneé, indicators of directions of former ice flows can be found in the slopes of Lučine (Fig. 13), Crno polje, Podotiš, Poljica s... Relatively well preserved polished surface are located above the main cirques and highest peaks of Prenj on the sides of Lučine, Zakantar, Gornja Tisovica, Poljica, and below Sivadija escarpments. They are under the recent influence of corrosion, cut by grikes. One of the more expressed in the relief, primarily shaped abrasion gla- 


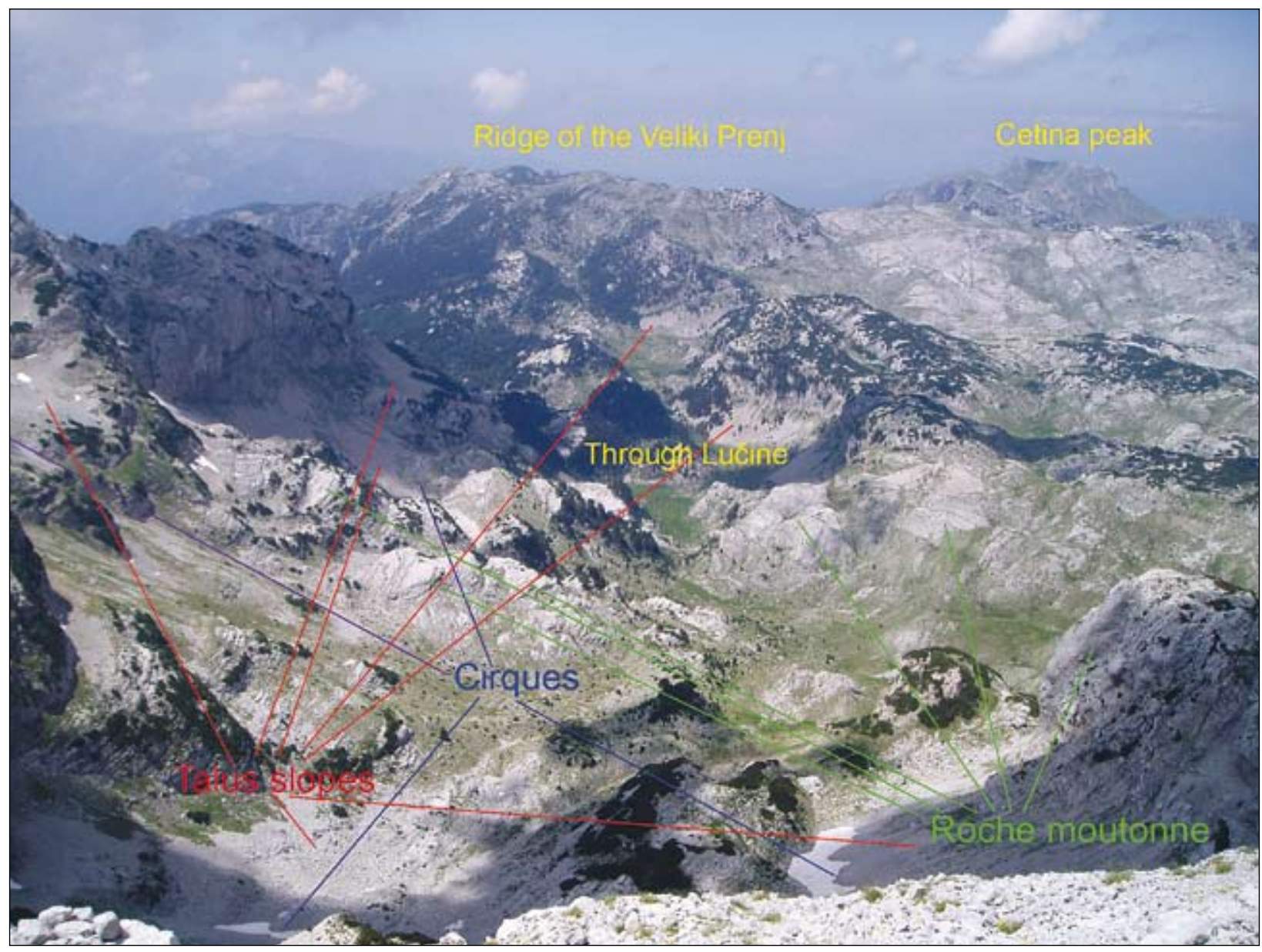

Fig. 13: Glaciokarstic relief of the western part of high central Prenj. The view from peak Lupoglav on the fossil through valley of Lučine bellow and the ridge of the Veliki Prenj1915 $m$ a.s.l. and Cetina $1991 \mathrm{~m}$ a.s.l. (photo: K. Muftić).

cier ice is subhorizontal polished surface in the eastern slopes of peak Lupoglav, $350 \mathrm{~m}$ long and with average width of around $50 \mathrm{~m}$.

Landforms of steep subglacially eroded steps, over $50 \mathrm{~m}$ high, can often be found in high mountain relief of the massif. Their glaciokarstic rocky faces are incised by ice erosion in eastern and western slopes of Lupoglav, eastern slope of Ovča, northern slopes of Otiš, Sivadija, Vidina kapa, Herać, western slopes of Osobac etc.

Decapitated shafts are evident in Prenj in subhorizontal surface of the south side of Čemerikovi doci at the altitudes of $1680 \mathrm{~m}$ a.s.l., in high central part (Fig. 14).

Similar landforms can be found in Azovi and Velika Provalija in the northeast of high mountain belt, at approximately same altitudes $1700-1750 \mathrm{~m}$ a.s.l. "They lead to destruction of functional relationship between the relief and the karst system, and to glacial dissection of pre-glacial cave systems. Stripping of the epikarstic zone and upper parts of cave systems on sub-horizontal surfaces results in prevalence of decapitated shafts in high mountains affected by glaciations" (A. Klimchouk 2006).

Moraines, erattics and drumlins point to the traces of glacial accumulation. Big boulders- eratics, which were transported by Prenj glaciers, can be found in the foot of the massif, most often in groups, rarely alone. Some landforms have dimensions bigger than $5 \mathrm{~m}^{2}$. In the former trough Konjička Bijela they are evident in several locations. The lowest position is at the altitudes of around $400 \mathrm{~m}$ a.s.l. near primary school in Mladeškovići. Also the same landforms are located in the forest area of Rakov laz and Brložine in higher positions (550-650 $\mathrm{m}$ a.s.l.). Discovered eratics in the foot of the massif can be found in the areas: upper and mid valley Idbar, upper valley Mostarska Bijela (above Pojila in beech wood on the right side of upper glacio-fluviokarstic gorge), in the valleys of tributaries of Glogošnica (in Suhava at around $250 \mathrm{~m}$ a.s.l.), Kljenova and Velika draga, at the edges of Hansko polje in the southeast of Prenj (at around $850 \mathrm{~m}$ a.s.l.). At the altitudes above $1300 \mathrm{~m}$ a.s.l. they are evident in the areas 


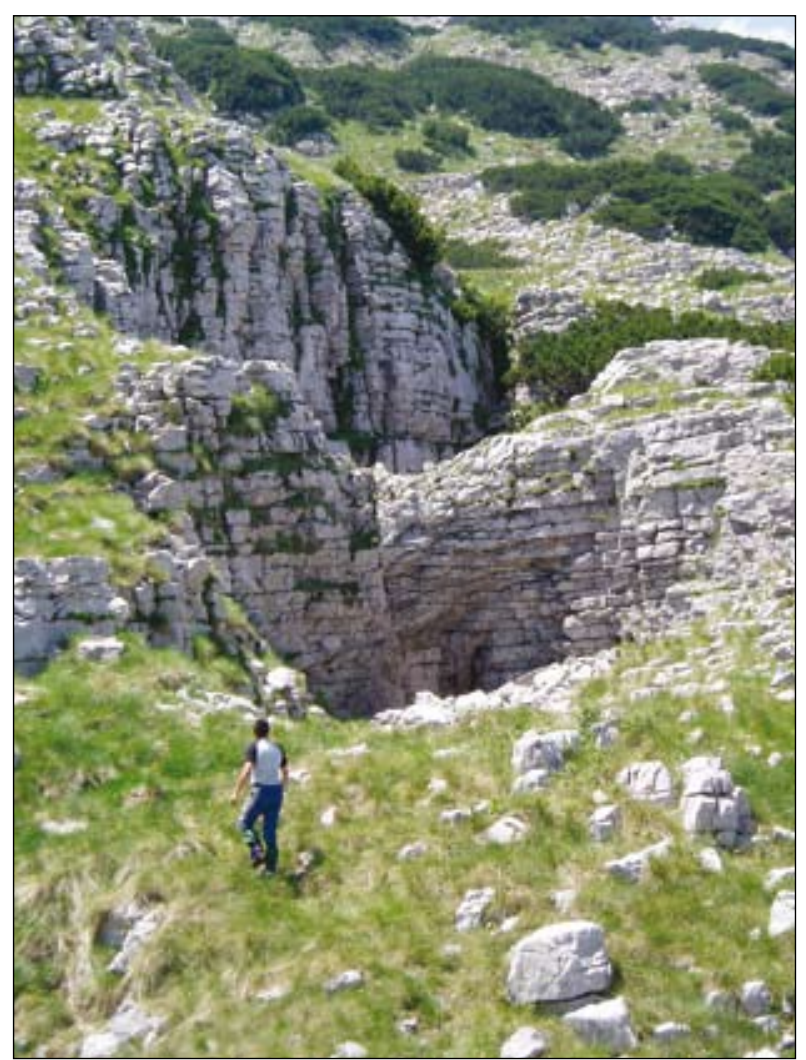

Fig. 14: Glaciokarstic landform - decapitated shaft in the Zakantar (photo: K. Muftić).

of: Crno polje, Jezerce, Bijele vode, Gornja Tisovica, Lučine etc.

Landforms of elongated oval shaped hills - drumlins up to $30 \mathrm{~m}$ high can be found in upper valley of Mostarska Bijela at $380 \mathrm{~m}$ a.s.l., in Suhava valley at 280 $\mathrm{m}$ a.s.l. as in the other low valleys in the foot of Prenj. Landforms are filled with unsorted clastic sediments. They were parallel extended with the past ice front.

Morianes drifts of the glacial till represented by heterogeneous, mealy and partially consolidated material: silt, clay, sand, gravel and boulders. They are discovered in the wider area of the researched are, including the mentioned main direction of ice flows and systems of Pleistocene glaciated valleys in Prenj (Fig. 10). Ground, lateral and end moraines of the mainly carbonate composition are represented in the massif relief. Recessional moraines, with which the uvalas of the high mountain belt are filled in, are shaped by the processes of melting and retreating of ice. Mountain uvalas are covered by the moraine forms gentle hills, and the typical example of this is the area of fossil trough (Fig. 10), which is now represented by the recent uvala Tisovica. Ground moraines fill in the bottoms of the shallow valleys and dragas. They are often covered by the soil and colluvial - prolluvial- alluvial drifts. Rounded rock debris of the subglacial ground moraines is spread along the low slopes (250-550 $\mathrm{m}$ a.s.l.) of the upper and on the left side central valley of Mostarska Bijela. In the neighboring terrains of Konjedol at the altitude of $280 \mathrm{~m}$ a.s.l. head moraines over $500 \mathrm{~m}$ long are discovered (Fig. 16). They are deposited by the hanging ice flow which moved from the cirque Stajetina from the altitude of $1700 \mathrm{~m}$ a.s.l. In the river basin Glogošnica, deposits are discovered in the scarp of the local road above confluence of Šanica with Ravašnica at around $200 \mathrm{~m}$ a.s.l. and in the river bed of Suhava and inclined hanging valleys. Villages Nuhići and Kasali in the valley of Idbar were developed on moraine fans (Fig. 10). The river bed of lower stream of Konjička Bijela is around $40 \mathrm{~m}$ deep incised into moraine drift which indicates very low firn line during glacial progression. The edges of Hansko polje at the altitude at around $850 \mathrm{~m}$ a.s.l. are covered by the end moraines of the southeast Prenj (Fig. 15). Moraines in the northwester part of Bijelo polje represent continuous extension of the glacial accumulation from Kljenova and Velika draga. "They are located at the very low altitudes at $105 \mathrm{~m}$ a.s.l. It should be mentioned in the literature unknown, around $700 \mathrm{~m}$ wide and differentiated moraine bank of glacier Rakov laz in the mouth Konjička Bijela in Neretva at the 285 $\mathrm{m}$ a.s.l and moraine Stranine (near lake Boračko jezero). Here it is emphasized the problem that was very little

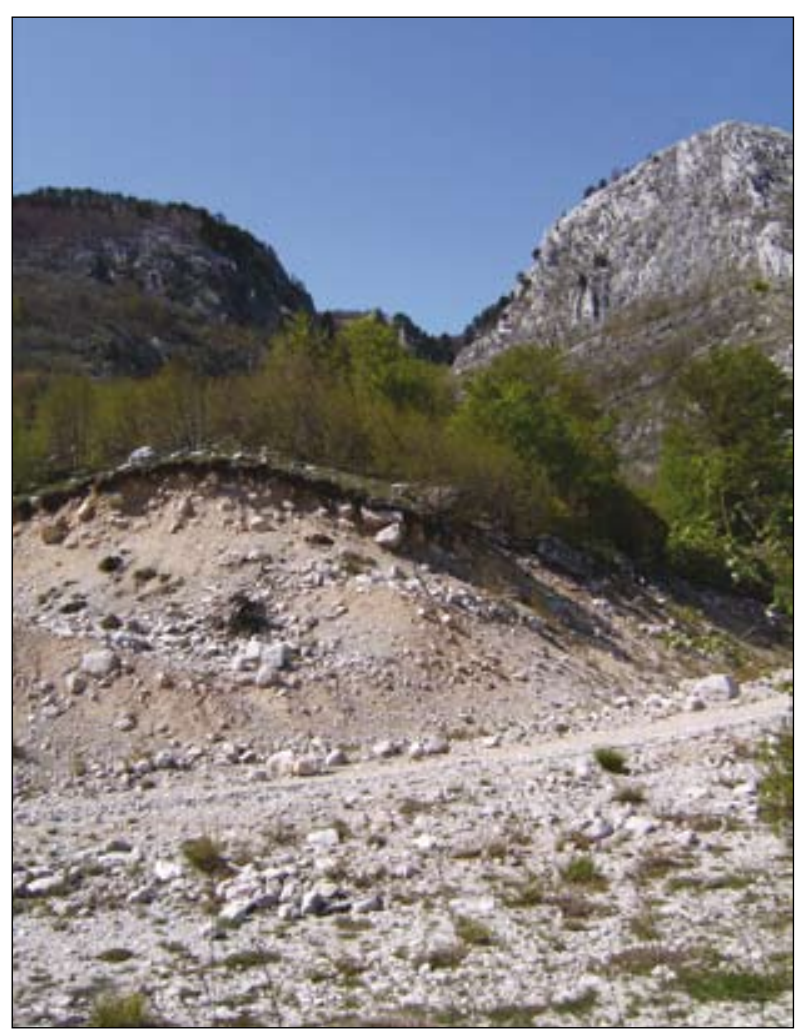

Fig. 15: Moraine drifts of southeast Prenj below Ruževača at 1100 m a.s.l. (photo: A. Lepirica). 


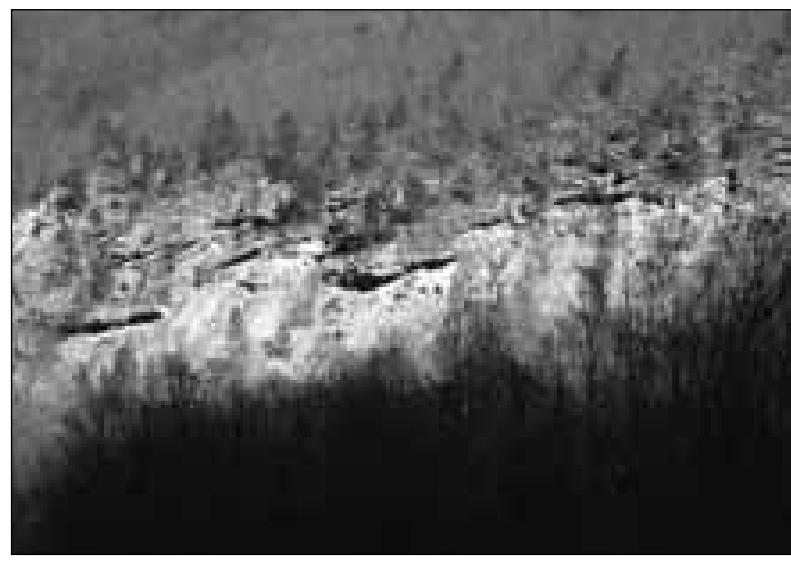

Fig. 16: Head moraines in Konjedol at $280 \mathrm{~m}$ a.s.l., on the left valley side of Mostarska Bijela (photo: A. Lepirica).

discussed before and that is activity of the glaciers in the sun exposed slopes on the low positions in Dinaric mountains" (Bakaršić 1967).

On the basis of spatial expansion and wide altitude range of appearances of erosional and accumulational glaciokarstic landforms we can emphasize that the massif, during the last glacial period was under an ice cap. Glaciation in the Prenj had regional characteristics with active glaciers of the trough valley, plates, hanging and cirque types. The lengths of the main glaciers were over $10 \mathrm{~km}$ at that time. In that period in the valleys of the Mostarska Bijela and Suhava the zone of ablation was very low, lower than $250 \mathrm{~m}$ a.s.l. (Fig. 10).

\section{GLACIO-FLUVIOKARSTIC LANDFORMS}

Two glacio-fluviocarstic gorges are deeply incised and shaped in the carbonate rocks of the upper valley of Mostarska Bijela (Figu. 10). Those are the narrow, 1$3 \mathrm{~m}$ wide, and over $30 \mathrm{~m}$ deep channels with open flat surface. The angles of the inclination of the smooth sides of the gorges are over $90^{\circ}$. Due to the numerous failures of the narrow river bed in the gorges, Bijela falls down in waterfalls which are in some places high up to $10 \mathrm{~m}$. With it turbulently shapes circular incised potholes with up to $4 \mathrm{~m}$ diameter. The first higher gorge is located upstream from Pojila, and it is around $0.3 \mathrm{~km}$ long, with the average stream fall of $30 \mathrm{~m}$. The second is deeply incised around $200 \mathrm{~m}$ downstream from the above. It is around $0.7 \mathrm{~km}$ long with the total stream fall of $110 \mathrm{~m}$. The lowest part of the lower gorge is cut with over $100 \mathrm{~m}$ long and narrow subhorizontal joint, from which permanent karst springs come out. The joint is parallely extended $3 \mathrm{~m}$ above the river bed. The genesis of the peculiar gorges landforms Mostarska Bijela was initiated by the erosion of melted subglacial water across developed joint lines in limestone bedrock during the final phase of the glacial period.
Humid and warmer periods of Holocene marked fluviokarstic development of landforms with contemporaneous uplifting of the limestone block, in which Bijela is deeply incised. Evorsion, which was a consequence of the flow of great mass of the drifts along the

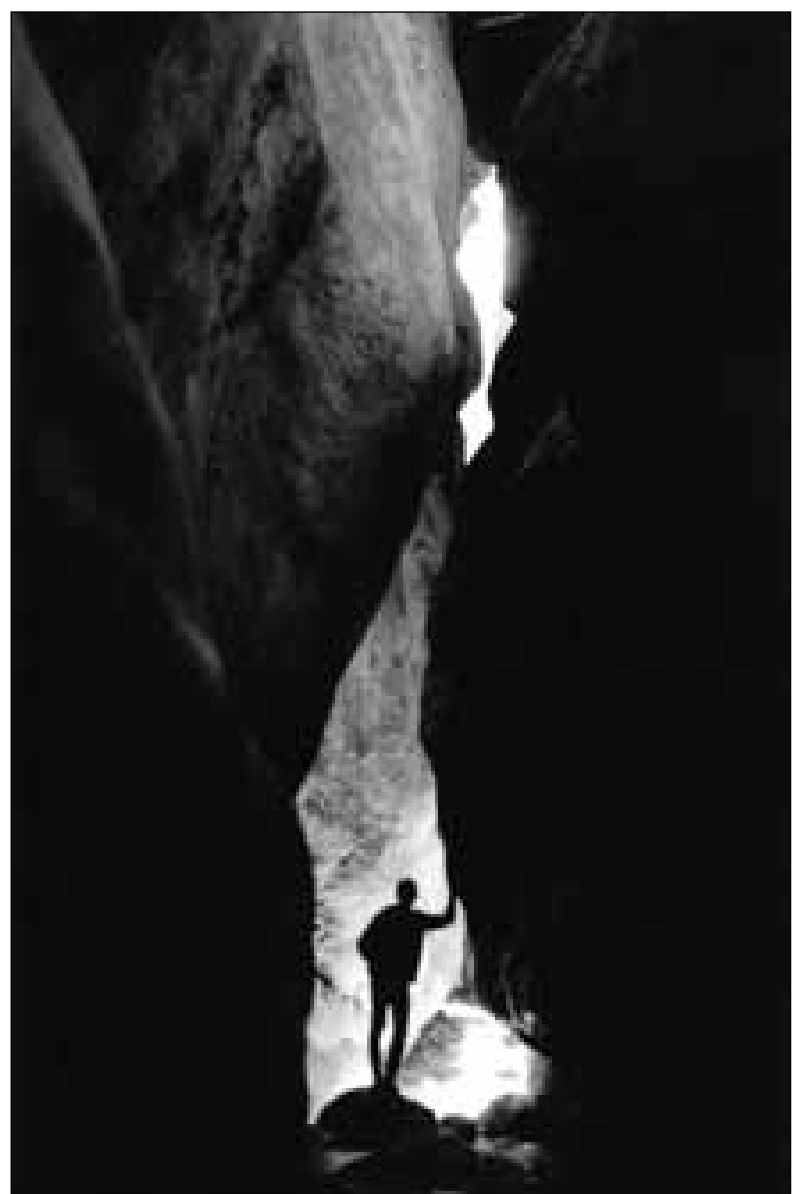

Fig. 17: Glacio-fluviokarstic gorge of the Mostarska Bijela, $30 \mathrm{~m}$ deep, average width 2-4 $m$ (photo: A. Lepirica).

narrow river bed, shaped potholes and smooth sides of gorges (Fig. 17).

A few dozen meters deeply incised channels in subvertical rocky walls located above the low valley morphosculptures. Those are the narrow and periodically humid depressions filled with recent mountain gullies. They originated by the erosional activities of the hanging glaciers, on the joints fissured carbonate surface, subsequently reshaped by deep corrosion of ice, snow melt water and rain water. Their narrow, deeply incised landforms can be found: in Korita in the southern slopes of Veliki Prenj, in the western slopes of Glogovo, in Konjedol above the central valley of Mostarska Bijela, in Duboki potok above the valley of Idbar, Jarmata, under Ruževača, above Rakov laz etc. 


\section{GLACIO-FLUVIAL LANDFORMS}

"Gravel drifts are deposed in the valley of Neretva, due to the Quaternary glaciation of the Mt. Prenj and Čvrsnica" (Grund, 1910). Conglomerated glaciofluvial terraces express the relief of the lower valley positions in the bottom of Prenj morphostructure. Their existence points out to the tectonic and climate changes in the younger period of Quaternary.

The representative example of not only this one, but also the wider area of Dinarides represent two bigger terrace levels in the valley widening of the middle flow of Neretva, with the total height of around $60 \mathrm{~m}$. Town Jablanica is located there. Grund named the older and higher level Jablanica terraces Postenterrasse and the younger and lower one Hotelterrasse. Conglomerates of the higher terraces are mostly constituted from the well cemented rounded blocks (diameter up to $1 \mathrm{~m}$ ) and predominantly from rounded debris of gabbro, limestone, schists etc. (Katzer 1903). In the composition of the lower terrace there are weaker agglutinated clasts - gravels and sands with the smaller amount of igneus rocks.

A bit down stream, on the opposite left side, there are neighboring terraces of Lug, which are correlative to the mentioned terraces of Jablanica. They are developed at the altitudes between 165 and $220 \mathrm{~m}$ a.s.l. and they relief express the footslopes of northwestern Prenj. They represent the highest and the most spacious terrace forms of the researched area. Their flat topped surface has the area of $0.4 \mathrm{~km}^{2}$. Subvertical scarp of the lower terrace that is around $30 \mathrm{~m}$ high is extended around 1.5 $\mathrm{km}$ above Neretva. The upper scarp of the higher- older terrace level is around $25 \mathrm{~m}$ high.

Terraces in the valley widening of Neretva, near Aleksin han and Donji Jasenjani are partially submerged in the mentioned artificial accumulations.

Glaciofluvial terraces of the Prenj valley have smaller spatial dimensions, and they are dissected by the periodical torrents (Fig. 10). Many are kept in fragments. The composition of these terraces contains predominantly carbonate conglomerates and breccia-conglomerates which are represented by the yellow-orange silts, gravels, sands and smaller boulders. They are cemented by the predominantly carbonate binders.

In the upper valley of Mostarska Bijela, the terrace landforms are mostly karstified (Fig. 18). Bellow their subvertical scarps, there is deeply incised upper glacio-fluviokarstic gorge Bijela. Spatially larger terrace is shaped in the left valley side with gently inclined topped surface at around $510 \mathrm{~m}$ a.s.l. It is around $0.6 \mathrm{~km}$ long and in some places wide up to $100 \mathrm{~m}$. Older-higher terrace scarps have darker color. They are composed of well cemented conglomerates and breccia-conglomerates which in the cold seasons of the year shatter under the

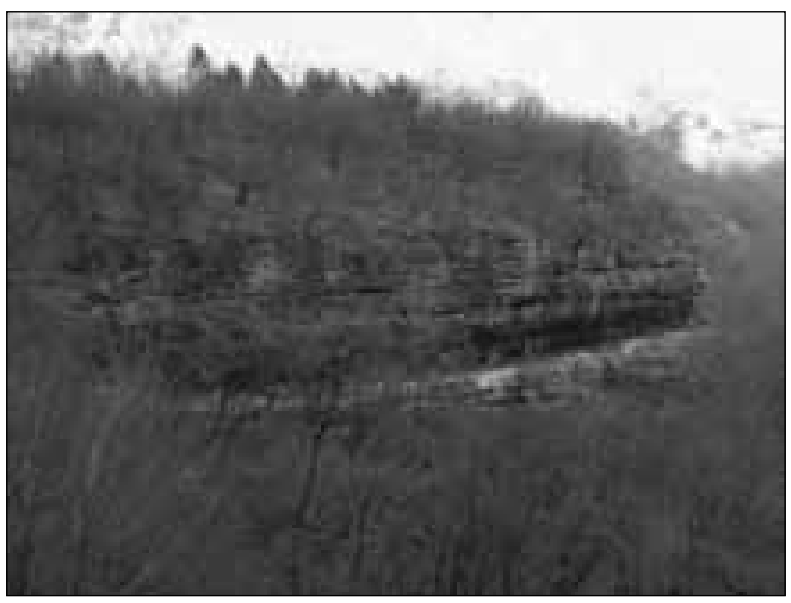

Fig. 18: Nothern scarp of the glacio-fluvial terrace of Mostarska Bijela (photo: A. Lepirica).

influence of physical weathering, thus breaking into the smaller blocks.

Terraces in the upper valley of Idbar are located at the approximately same altitudes as the above mentioned terraces of Mostarska Bijela, from which they are around $10 \mathrm{~km}$ far in the direction of northeast. The same altitude position of their flat topped surfaces at the opposite edge of the massif can point out to the unequal neotectonica uplifting of the block of the high central Prenj in the younger period of Pleistocene and during Holocene.

Flattened terraces surface of Konjička Bijela are located at around $400 \mathrm{~m}$ a.s.l. in the lower valley between Mladeškovići and Jošanica. They are developed and shaped on the both valley sides, and the height of the terrace scarps is up to $40 \mathrm{~m}$.

On the left side of the lower valley of Suhava at the altitude at around $190 \mathrm{~m}$ a.s.l. there is a narrow, around $400 \mathrm{~m}$ extended conglomerate terrace. The remaining glacio-fluvial terraces of the researched area are less expressed in the valley relief.

The flattened bottom of the central valley of Mostarska Bijela is around $3 \mathrm{~km}$ long, with the average width between $100-120 \mathrm{~m}$. It is filled with volumes of rock, rounded debris - sand, gravels and small boulders. In this area braided flow Bijela is makes shallow and side incision through thick alluvial, prolluvial and glaciofluvial drifts which are deposited by ice melted water of the Prenj glaciers in the recessional period of glaciation.

\section{PERIGLACIAL PROCESSES AND FORMS}

Periglacial processes of cryonivation, cryofraction, cryoturbation and solifluction participate in recent shaping of the landforms of higher part of Prenj. Due to the low temperatures they are active during winter, early spring and late fall. They influence on disintegration of near-surface rocky complex and mountain soil. The recent periglacial 
environments of the mountain uvalas, ridge slopes and crests, and the bottom of the escarpments Prenj mark in the relief stone stripes, angular debris and landforms block fields and blockstreams. (Fig. 19).



Fig. 19: High mountain karst of Zakantar in the central Prenj. The sides of doline are shaped in concordant Dogger limestone layers at $1600 \mathrm{~m}$ a.s.l., abraded by glacial erosion, reshaped by periglacial and karst processes in Holocene. On the right side it is visible the process of edge-widening of doline, caused by frost shattering of carbonate rocks along subhorizontal joint (photo: K. Muftić).

Nivation lasts more than six months. In the early spring, at the altitudes higher than $1500 \mathrm{~m}$, snow deposits reach heights of few meters. On the mountain slopes, this forms continuous avalanche corridors of the great destructive power. They destroy slope surfaces. In the shadowed higher slopes of the massif, the snow patches fill the nivation hollows in which they are kept until August. Many of these hollows represent fossil cirques, subsequently reshaped by periglacial processes during Holocene. The biggest are: Rupčine in the northeastern slopes of Konjička Bjelašnica, Rov in the east of Cetina peak, Zagon in the northeastern slopes of Kanter etc. One of the lowest permanent snow patches in Dinarides is the short firn snow patch which exists above the Zubac peak at the altitude of $1100 \mathrm{~m}$ a.s.l.

The corrosion of carbonate rocks is intensified by the activity of snow and ice melted water in the wider mountain area, which results in development of karren fields are cut by numerous grikes, several meters deep.

Cryonivation influences on smoothing and lowering of the landforms. The biggest levels of planation in the researched area represent cryoplanation levels shaped by cryonivation processes in three altitude levels. They are genetically younger that the mentioned pediments with the gently inclined surfaces with the inclination between $7^{\circ}-11^{\circ}$. Spatially they encompass less than $0.4 \mathrm{~km}^{2}$. They are parallely extended along the main ridges above. The lowest level is discovered in the south slopes of the central Prenj, with the altitudes of around $1550 \mathrm{~m}$ a.s.l. northwestern and southeastern from Stajetina, in Rive and Kapljuč. Subhorizontal planes of the second level encompass Gladišta below Veliki Prenj and southern slopes of Kantar between 1650 and $1680 \mathrm{~m}$ a.s.l. The highest - third cryoplanation level encompasses eastern, top parts of the extended ridge of Veliki Prenj, at the altitudes between 1770-1780 m a.s.l.

The intensive freezing influences on cracking and shattering of the rocks and shapes the sharp forms of Prenj serrated peaks, monoliths and stone towers. The influence of the frost shattering in the high and steep, rocky slopes leads to mass movements and development of talus slopes - the big, rocky fall blocks and debris that are over $1 \mathrm{~km}$ long (Izgorjela gruda, Sivadije, Otiš, Lupoglav, Osobac, Vjetrena brda etc.). Scree creeping that occurs on talus slopes between the cracks is caused by the periglacial processes of the freeze-thow. Those taluses slowly creep down the slope. During winter, the cryofraction in Boračka, Velika and Kljenova draga and in the upper valleys of Idbar, Mostarska and Konjička Bijela is very expressed, when the icicle over $30 \mathrm{~m}$ high destroy surrounding shadowy rocky scarps.

Solifluction freeze-thow processes of the creeping of the moist regolith are frequent in the short time intervals. They are resulted in micro landforms of the inactive and active stone and turf mantled solifluction lobes. They can be found on the slope surfaces above $1600 \mathrm{~m}$ a.s.l. in: Konjička Bjelašnica, Sivadija, Osobac, Kantar, Cetina, Veliki Prenj, Kopilice etc. The high mountain uvalas Tisovica, Poljica, Vlasni dol, Crno polje are filled with gently undulated hill forms of the moraine drifts., Solifluction, apart from the other geomorphic processes, influences on their recent reshaping.

\section{FLUVIODENUDATIONAL, FLUVIAL AND FLUVIOKARSTIC RELIEF}

Fluviodenudational relief is represented in the bed rocks with more or less impermeable layers. Fluviodenundational landforms of the low valleys are deeply incised over $1000 \mathrm{~m}$ in the Prenj massif (Fig. 8). They are represented by linearly elongated composite morphosculptures: Idbar $(10 \mathrm{~km})$, Glogošnica $(7 \mathrm{~km})$ Konjička Bijela $(9 \mathrm{~km})$ and Mostarska Bijela $(11 \mathrm{~km})$. In the wide areas of the valleys they reach up to $0.5 \mathrm{~km}$ of width. Those are polymorphic and polyphase landforms, usually $U$ shaped transversal profile. They are faulted predisponed and fluviodenundationally shaped.

Valley sides orographically express lower steep slopes of the massif exposed to the influence of active, destructive denudational-erosional processes. In 
their contact with subhorizontal bottoms of the valleys, prolluvial cones and prolluvial fans are formed, represented by the older inactive and younger recent active screes. In the edge area of the valleys of Mostarska Bijela, Konjička Bijela, Idbar, and Glogošnica they are connected in prolluvial zone that is several kilometers long. The biggest zone of prolluvial accumulation, originated from dragas of the south Prenj, is north part of the basin of Bijelo polje, which is $5 \mathrm{~km}$ long. Gently inclined valley bottoms are elongated at the altitudes lower than $600 \mathrm{~m}$ a.s.l. (Fig. 10). They are filled with a few dozens of thick layers of Quaternary drifts, in which composition predominate: gravels, sands, clay and small boulders. It is easy to notice cross stratification of the mutually mixed mealy alluvial and prolluvial deposits, with which the older moraine drifts are covered. Subhorizontal valley planes are represented by fluvial accumulation landforms: alluvial fans, flood plain, inundational teraces and prolluvial fans and cones. They morphogenetically express the youngest generation of the relief. The lowest positions are marked by the shallow incised river beds: Idbar, Glogošnica, Konjička and Mostarska Bijela.

Fluviokarstic relief is predominantly represented in dolomite terrains, in the northwest, north and northeast parts of Prenj, which is dissected by the fluviokarstic derasional valleys. Those are inclined, narrow, and elongated landforms through which flow permanent streams: Draganska rijeka, Šanica, Ravašnica and Bijela (tributaries of Glogošnica), Jeverišnjak (tributary of Idbar), and Ribišnica (tributary of lake Jablaničko jezero). They represent smaller torrent streams, up to $5 \mathrm{~km}$ long, which according to Strahler's classification (1957) belong to the lowest categories.

Tectonically predisponed fluviokarstic gorge of Neretva is extended in the area of Donja Jablanica to Salakovac in the length of $25 \mathrm{~km}$. It is incised between mountain morphostructures of Prenj and Čvrsnica (Fig. 10). It is of asymmetrical V profile, and in some places deep up to $1200 \mathrm{~m}$. Its left valley sides express ending west and southwest escarpments of the karst plateau Glogovo. Fluviokarstic river bed of Neretva and the low sides of gorge are submerged with a few dozen meters in depth artificial accumulation huge dam: "Grabovica" and „Salakovac". Fluviokarstic gorges of Idbar, Mostarska Bijela and Bijela (left tributary of Glogošnica) are of much smaller dimensions, long less than $1 \mathrm{~km}$. They are shaped by deep fluvial erosion in dolomites. Narrow incised fluviokarstic beds of these streams are marked by the occurrences of waterfalls, cascades and evorsional shapes potholes. They are filled with massive drifts. The process of corrasion is active.
The water of Mostarska Bijela and Glogošnička Bijela have accumulated in the river beds smaller amounts of indissoluble $\mathrm{CaCO}_{3}$ - calcareous sinter.

\section{ANTHROPOGENIC RELIEF}

In the researched mountain area, so far relatively limited anthropogenic influences can be seen. Anthropogenic relief is the most expressed in Prenj valleys and in the lower pediments. It is represented in: rural settlements with corresponding infrastructure, seasonal shepard settlements, mountain - hunting cottages and telecommunication objects, roads, mountain paths, abandoned mines, remaining mine fields and local waste depositions.

Rural settlements with the surrounding agricultural area are concentrated in the low valleys of Glogošnica, Idbar, Konjička Bijela and low pediments of Jasenjani and Ravni They are connected with the municipal centers in the main Neretva valley with narrow asphalt and macadam roads. Some of them are abandoned as Grabovčići and Bijela. Former seasonal shepard settlements, spread all over Prenj, are mostly abandoned. During the warmer part of the year, the only active ones are on Rječica, Ljubina, Kiser and Tisovica. The mountain and hunting lodges have smaller capacity. Many of them were destroyed during the war in Bosnia and Herzegovina. The most visited, at this moment, are the mountain lodges in Rujište and Ljubina, and recently reconstructed lodge in Bijele vode. Telecommunication transmitters in Glogovo, Rječice and on top of Borašnica are the highest anthropogenic objects of the researched area.

In the modern time, the human influence is more and more expressed in the area of this Herzegovinian mountain. It is marked by the wide specter of disturbance of the balans of natural processes. Unplanned construction of the network of mountain roads, incised in steep slopes and intensive devastation of the elite beech (Fagus montanum) and endemic woods of black pine (Pinus nigra) and Bosnian pine (Pinus heldreichii) influence on acceleration of destructive denudational processes.

Abandoned mines of iron, hematite and manganese are located in the lower areas of northern part of the massif near Šuplji kuk, Brložine and Mraka, and bauxite near Jasenjani in the southwest.

The areas in the east, southeast and a microlocation in the central, northwest and north part of the massif have been contaminated by the mine fields during the previous war in Bosnia and Herzegovina. Local waste deposits of the municipality Konjic is located on the slopes of Vrabač in the northeast slopes of Prenj. 


\section{CONCLUSIONS}

The massif Prenj (2103 m a.s.l.) is developed and shaped in the Bosnian and Herzegovinian Dinaric karst. It is dissected over $1000 \mathrm{~m}$ deep incised valleys of Neretva, Idbar, Konjička Bijela, Glogošnica and Mostarska Bijela.

Lithological composition of the terrain is predominantly characterized by Triassic, Jurassic and Cretaceous limestones and dolomites. Gently folded layers, thrusts, faults, fault zones and tectonic windows structurally express this neotectonic active area.

From morphostructural aspect, Prenj is foldedthrusted mountain massif of Tertiary and pre-Tertiary folding with particular uplifting in the Pliocene-Quaternary. It is tectonically represented by three blocks fissured by numerous reverse and normal faults. Two main stronger faults, that are over $15 \mathrm{~km}$ long, express structural - lithological borders of Prenj blocks within mountain area.

Dynamic relief plastic of the terrain is marked by mountain ridge crests with slope fans perpendicularly directed toward subhorizontal terrains of the mountain plateaus, uvalas, pediments and deeply incised valleys and basins. It is marked by hypsometrical complexity and emphasized values of the relative relief, which reaches $975 \mathrm{~m} / \mathrm{km}^{2}$.

Fault neotectonic has predisposed genesis and development of the relief forms and directed geomorphic processes in this massif.

The high degree of correlation between the relief and lithological composition is identified, and it can be seen in reticular relief structure developed in carbonates and ribbed fluviodenudational relief of the sub-mountain belt in the north, shaped in more-less impermeable Lower-Triassic clasts.

Relief is of polymorphic, polygenetic and polyphase character. Wide slope areas are marked with the recent development of destructive denudation processes: mass movements, erosion, corrosion, cryogenic etc. while the main accumulation zones of the thick Quaternary drifts are concentrated at the bottom of the low valley pits. Glaciokarstic and periglacial relief dominates at the altitudes above $1500 \mathrm{~m}$ a.s.l., it encompasses area of approximately $100 \mathrm{~km}^{2}$. On the basis of the conducted field observations of geomorphological traces of glaciation it is determined that the massif was under an ice cap during the last glacial period. The zones of ablation were located lower than $250 \mathrm{~m}$ a.s.l., and the lengths of the biggest Prenj glaciers were over $10 \mathrm{~km}$. The karst relief is represented at karst denudational plains of Glogovo, mountain uvalas and occasional subcutaneus karst at the altitudes bellow $1500 \mathrm{~m}$ a.s.l. Prenj is marked by hydrogeological characteristics of high and deep Dinaric karst. Fluviodenudational, fluvial and fluviokarstic relief encompasses low, composite, obsequent valleys and mountain footslopes shaped in impermeable low triassic layers of bed rocks. Anthropogenic relief and the influence of the modern man are limited to smaller areas of low valleys and narrow belts of forest roads.

In geomorphological sense, the analyzed part of the area is located in macrogeomorphologic entity High Bosnia-Herzegovinian Karst as subunit of the megageomorphologic entity Dinaric Mountain System. Within the mentioned macro-unit, respecting the stated criteria of regionalization (similarity of morpho-evolutionary, structural-lithological and orographical characteristics) a mezogeomorphological unit - Mountain Massif Prenj is singled out, and described in this work. "In taxonomic unit of geomorphological subregion are included relief units of geomorphologically same type, which are connected morpho-evolutionally, but in respect to their surroundings are composed out of morphofacies groups which are more or less autonomous features in structural and orographic sense" (Bognar, 2001). By detailed spatial differentiation of geomorphological features of the researched mountain areas, three Prenj subregions are singled out: 1. Mountain Ridges of the North and Northeast Prenj, 2. High Mountain Group of the Central Prenj, 3. Karst Plateau Glogovo.

\section{REFERENCES}

Anđelković, M., 1982: Geologija Jugoslavije - Tektonika.Rudarsko-geološki fakultet, 692, Beograd.

Bakaršić, S., 1967: Tragovi glacijalnih i periglacijalnih procesa u Mostarskoj kotlini.- Geografski pregled XI-XII 47-82, Sarajevo.
Belisario, F., Del Monte, M., Fredi, R., Funicielo, R., Lupia Palmieri, E. \& Salvini, F., 1999: Azimythal Analysis of Stream Orientations to Define Regional Tectonic Lines.- Z. Geomorph., Suppl.-Bd. 118: 41-63, Berlin - Stuttgart. 
Bognar, A., 2001: Geomorfološka regionalizacija Hrvatske.- Acta Geographica Croatica, 34, 7-29, Zagreb.

Cvijić, J., 1895: Karst.- 135, Beograd.

Cvijić, J., 1924-26: Geomorfologija I.- Beograd.

Cvijić, J., 1924-28: Geomorfologija II.- Beograd.

Čičić, S., Mojićević M. \& Papeš J., 1984: Geologija Bosne i Hercegovine, Knjiga II, Mezozojske periode.Geoinženjering, 315 Sarajevo.

Donassy, V., Oluić M. \& Tomašegović, Z., 1983: Daljinska istraživanja u geoznanostima.- JAZU, Zagreb.

Grund, A., 1910: Beiträge zur Morphologie des Dinarischen Gebirges.- Geographische Abhandlungen, Band IX, Heft 3, Leipzig und Berlin.

Herak, M., 1983: Geologija.- Školska knjiga, 433, Zagreb.

Huggett, R. J., 2003: Fundamentals of Geomorphology.Routledge, 400, London and New York.

Katzer, F., 1903: Geologischer Führer durch Bosnien und der Hercegovina, Sarajevo.

Katzer, F., 1909: Karst und karsthydrographie.- Instituts für Balkanforschung in Sarajevo, 94, Sarajevo.

Klimchouk, A., Bayari, S., Nazik, L. \& Törk, K., 2006: Glacial destruction of cave systems in high mountains, with a special reference to the Aladaglar Massif, Central Taurus, Turkey.- Acta Carsologica, 35, 2, 111-121, Ljubljana.
Lepirica, A., 2005: Geodiverzitet planine Čvrsnice.Fondeko br. 19., Sarajevo.

Marković, M., 1983: Osnovi primenjene geomorfologije.Geoinstitut, 123, Beograd.

Milanović, P., 1979: Hidrogeologija karsta $i$ metode istraživanja.- Institut za korištenje i zaštitu voda na kršu, 302, Trebinje.

Moičević, M. \& Laušević, M., 1973: Tumač za list Mostar, K 33-24. Osnovna geološka karta SFRJ 1 : 100 000.Savezni geološki zavod, 42, Beograd.

Spiridonov, A. I., 1975: Geomorfologičeskoe kartografirovanie.- Nedra, 182, Moskva.

Sthraler, A. N., 1957: Quantitive analysis of watershed geomorphology.- American Geophysics Union Trans., vol., 38.

Sweeting, M. M., 1972: Karst Landforms.- The MacMillan Press, 362, London.

Šegota, T. \& Filipčić, A., 1996: Klimatologija za geografe.Školska knjiga, 471, Zagreb. 
